\title{
The "Non-Cumulation Clause": An "Other Insurance” Clause by Another Name
}

\author{
Christopher C. French ${ }^{*}$
}

\section{INTRODUCTION}

Imagine a corporate policyholder that is facing tens of millions or even hundreds of millions of dollars in liabilities for events and injuries that occurred years, if not decades, in the past. These liabilities threaten the very financial solvency and future of the company. Imagine further that, although the policyholder has dozens of insurers and insurance policies to cover the liabilities, none of its insurers agrees to pay anything. Instead, in addition to a litany of defenses that the policyholder is forced to defeat through years of litigation, at the end of that long fight each insurer contends that it nonetheless should have no liability because insurers other than itself should pay instead. Now, imagine being the judge who must decide which of the dozens of insurers should pay and how much each one should pay. The scenario described above is not fictional. It is a scenario that plays out regularly in the world of insurance coverage litigation regarding long-tail liability claims.

One of the most factually and legally complex issues courts are asked to resolve in insurance coverage disputes that involve long-tail claims such as asbestos bodily injury claims and environmental claims, which have damage processes that span multiple policy years, is how the liabilities associated with the claims should be allocated among the numerous policy years that often are triggered by such losses. The courts' resolution of this critical issue may shift responsibility for millions or tens of millions of dollars of liabilities from one party to another.

\footnotetext{
Partner, K\&L Gates LLP, Pittsburgh, Pennsylvania; Adjunct Professor of Insurance Law, Duquesne Law School; J.D., Harvard Law School; B.A., Columbia University. The author gratefully acknowledges the legal research contributions of Kimberly Geary, Gregory Sturges, and Cody Corliss to this Article. The views expressed in this Article are those of the author and not necessarily those of K\&L Gates LLP or any of its clients.
} 
Because insurance companies are in the business of making money - that is, their goal is to pay out less money in claims payments and costs of doing business than they receive in premiums and investment income-they continuously are looking for ways to minimize or eliminate their obligations to pay long-tail claims even after it has been determined that their policies have been triggered by a loss. To that end, certain insurers have turned to a provision often found in commercial general liability (CGL) policies-the "Prior Insurance and Non-Cumulation of Liability Clause," referred to herein simply as the "non-cumulation clause"-as a linguistic vehicle they attempt to use to minimize or eliminate their payment obligations after a court or jury has determined that their policies have been triggered by a loss.

The non-cumulation clause commonly found in historical London market umbrella liability policies, for example, states as follows:

It is agreed that if any loss covered hereunder is also covered in whole or in part under any other excess policy issued to the Assured prior to the inception date hereof the limit of liability hereon ... shall be reduced by any amounts due to the Assured on account of such loss under such prior insurance. ${ }^{1}$

In essence, the insurers' argument is that the non-cumulation clause shifts the responsibility for paying for losses that trigger multiple policy years to any and all triggered insurance policies that were issued prior to their own policy year. Thus, even after it has been determined that the loss triggers their policy year, these insurers point to the non-cumulation clause and then attempt to reduce, or completely eliminate, their payment obligations on the grounds that all of the liabilities associated with the loss should be reallocated to only policy years that predate their own (invariably another insurer's policy year). Under the insurers' argument, if the policies in the earlier triggered policy years have unpaid limits, then the limits of those policies should pay until their limits are exhausted. If the limits of the policies in the earlier triggered policy years have been exhausted by settlements or prior payments of unrelated claims, then, according to these insurers, the policyholder becomes selfinsured for the remaining amount of the loss-that is, the policyholder receives nothing from the insurers, even though the policyholder paid a

1. See, e.g., Stonewall Ins. Co. v. E.I. du Pont de Nemours \& Co., 996 A.2d 1254, 1259 (Del. 2010); Westinghouse Elec. Corp. v. Am. Home Assurance Co., Nos. A-6706-01T5, A-6720-01T5, 2004 WL 1878764, at *19 (N.J. Super. Ct. Law Div. July 8, 2004) (per curiam). 
premium for the policies, the policies have been triggered, and the policies' limits have not been exhausted.

This Article explains that non-cumulation clauses were never intended to apply to long-tail claims in the manner certain insurers now contend they should. When the clauses were first drafted, the original drafters of the clauses did not intend for the clauses to apply to long-tail claims-like asbestos bodily injury and environmental property damage - because such claims were not even recognized as such, and the allocation schemes developed to address such claims had not yet been adopted by the courts.

Indeed, non-cumulation clauses such as the London version quoted above are hopelessly ambiguous when applied to long-tail claims. This ambiguity is revealed when one attempts to apply the clause literally to long-tail claims by considering questions such as the following: How does one determine whether a loss is "covered" under a prior-incepting policy when the prior-incepting policy has not been included in the case because of settlements, exhaustion, or some other reason? Must the issuer of the prior-incepting policy admit, which is unlikely, that its policy "covers" the loss? How can amounts be "due” from insurers from which the policyholder is not even seeking to recover? To whom would the amount be "due" in such circumstances? Is an adjudication required regarding the responsibilities of the prior-incepting policies before amounts are "due" from them? Would such a result even be legally binding on insurers that issued the prior-incepting policies if they are not parties in the case? These are just a few of the questions that reveal the ambiguity of non-cumulation clauses when they are applied to long-tail claims.

This ambiguity is further highlighted by the fact that the courts that have attempted to apply such clauses cannot agree on the clauses' meaning or application. Stated differently, it is hornbook insurance law that a non-cumulation clause must be "unambiguous"-have only one reasonable meaning-when applied to long-tail claims before the insurer's argument seeking to defeat coverage can be accepted. Yet, if the numerous courts that have considered such clauses-including the courts that have held such clauses are "unambiguous"-cannot even agree on the meaning and application of such clauses, how can such clauses be "unambiguous"?

In addition to this introduction and a conclusion, this Article examines the interpretation and application of non-cumulation clauses with respect to long-tail claims in four parts. Part II sets forth the factual background necessary to discuss the issue, which includes the typical 
structure of commercial insurance programs, the nature of long-tail claims, the various trigger and allocation schemes that have been adopted by the courts, and the history of the drafting of one of the most common versions of the clause-the London version. Part III examines the courts' inconsistent interpretations and applications of non-cumulation clauses. Part IV discusses the principles of insurance policy interpretation-such as the doctrines of contra proferentem and "reasonable expectations"-and how such principles apply to the interpretation and application of non-cumulation clauses to long-tail claims. Finally, Part V suggests the proper interpretation and application of non-cumulation clauses in the context of long-tail claims. This Article concludes that non-cumulation clauses, using the London version as an example, are ambiguous when applied to long-tail claims. Consequently, courts should construe the clauses in favor of the policyholder such that the policyholder can and should recover the full amount of its covered liabilities to the extent the triggered policies' limits are sufficient. Because non-cumulation clauses purport to shift liability for a loss from one insurer to another insurer, they essentially are variations of "other insurance" clauses. Thus, after the policyholder has been paid in full for its covered liabilities, the non-cumulation clause should apply, if at all, in contribution claims between insurers to determine their respective obligations in the same manner as "other insurance" clauses.

\section{THE FACTUAL AND LEGAL BACKGROUND IN WHICH NON- CUMULATION ClAUSES ARE INTERPRETED AND APPLIED}

\section{A. Typical Insurance Programs}

Historically, many commercial policyholders have purchased "occurrence"-based liability insurance annually to ensure that they have seamless coverage for losses that span multiple policy periods. Such programs typically have multiple layers of coverage with primary insurance at the lowest level and excess insurance above the primary insurance, with the total limits of insurance in each policy year increasing as time moves forward. ${ }^{2}$ The policy language in all of the policies in the various policy years often is the same or similar because commercial liability insurance policies are drafted by the insurance

2. See infra Figure 1. 
industry and used by most insurers. ${ }^{3}$ A graphic depiction of a typical insurance program of a commercial policyholder appears in Figure 1.

\section{Figure 1: Typical Insurance Program of a Commercial Policyholder}

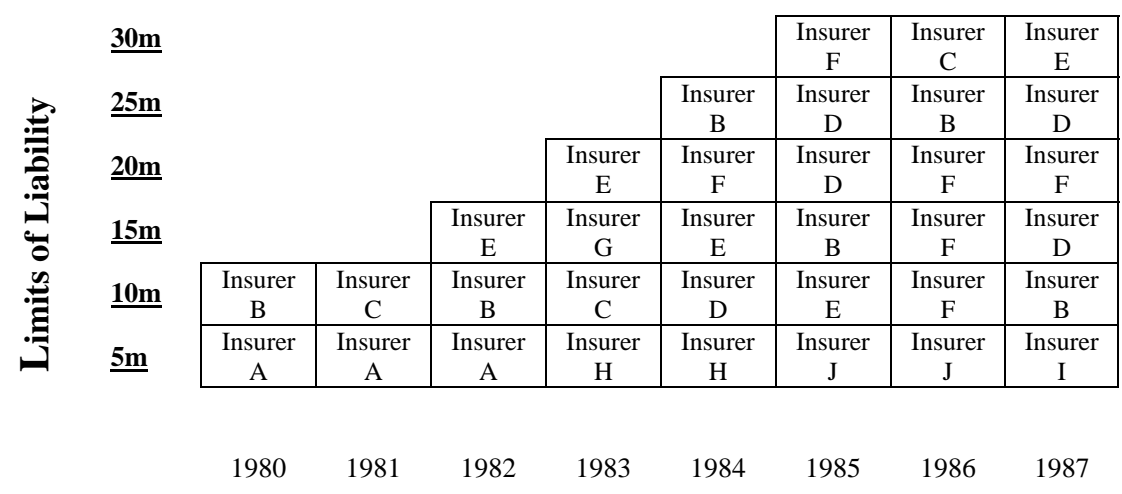

\section{Policy Period}

Under the hypothetical insurance program reflected in Figure 1, if a covered liability in the amount of \$18 million triggered only the 1984 policy year, then Insurer $\mathrm{H}$ would pay the first $\$ 5$ million, Insurer $\mathrm{D}$ would pay the next \$5 million, Insurer E would pay the next \$5 million, and Insurer $\mathrm{F}$ would pay the final \$3 million. In long-tail claims where a covered liability implicates multiple years and layers of coverage, the determination of each insurer's liability is more complex. For example, assume that a covered loss totals $\$ 30$ million and it has been determined that the damage process giving rise to the liability began in 1980 and ended in 1986. What is Insurer E's coverage obligation? As one might suspect, answering that question is a more difficult task.

3. See, e.g., Holmes' ApPleman ON Insurance § 129.1 (2d ed. 2010) (noting that the "insurance industry voluntarily set about to standardize CGL insurance contract language"); Nancy Ballard \& Peter M. Manus, Clearing Muddy Waters: Anatomy of the Comprehensive General Liability Pollution Exclusion, 75 CoRnelL L. REV. 610, 622-23 (1990) (noting that in the 1940s, "the National Bureau of Casualty Underwriters ('NBCU'), consisting of employee-representatives of stock insurance companies, and the Mutual Insurance Rating Bureau ('MIRB'), consisting of employee-representatives of mutual insurance companies," jointly drafted the basic provisions of the CGL policy to be used on an industry-wide basis). 


\section{B. Typical Long-Tail Claims: Asbestos Bodily Injury and Environmental Property Damage}

Asbestos bodily injury and environmental property damage claims are typical long-tail claims. ${ }^{4}$ Asbestos was used in numerous productsfrom gloves to insulation-because of its heat-retardant qualities. ${ }^{5}$ Consequently, an individual's exposure to asbestos historically may have occurred in numerous places over the course of many years. ${ }^{6}$ Once asbestos fibers enter an individual's lungs, a progressive disease process can begin that progresses over many years and ultimately can result in deadly diseases such as mesothelioma and lung cancer. ${ }^{7}$

4. Jeffrey W. Stempel, Assessing the Coverage Carnage: Asbestos Liability and Insurance After Three Decades of Dispute, 12 ConN. INS. L.J. 349, 375 (2006) ("Because injury continues to be inflicted anew by asbestos fibers in the lungs, consecutive liability policies are triggered.”). For a detailed discussion of insurance and asbestos liability, see, for example, id.

5. See BellSouth Telecomms., Inc. v. W.R. Grace \& Co.-Conn., 77 F.3d 603, 606 (2d Cir. 1996) ("Asbestos is a flame-retardant and heat-resistant fibrous mineral that was commonly used in fireproofing in buildings, ships, and protective fireproof garments at least as early as the nineteenth century.”); Johns-Manville Corp. v. United States, 855 F.2d 1571, 1571 (Fed. Cir. 1988) (per curiam) ("Due to the heat resistant and fire retardant properties of asbestos it was used in insulating ships' boilers, steam pipes, pumps, and other equipment.”); Borel v. Fibreboard Paper Prods. Corp., 493 F.2d 1076, 1083 n.3 (5th Cir. 1973) ("[Asbestos] was used as an insulator against heat as early as 1866, and asbestos cement was introduced about 1870.”); STEPHEN G. CARROLL, ET AL., RAND InST. For Civil JUSTICE, AsBestos LiTIGATION 11 (2005) (noting the wide use of asbestos because the product is "strong, durable, and has excellent fire-retardant capability"), available at http://www.rand.org/content/dam/rand/pubs/monographs/2005/RAND_MG162.pdf.

6. See CARROLL ET AL., supra note 5, at 11-12.

7. See, e.g., Norfolk \& W. Ry. Co. v. Ayers, 538 U.S. 135, 168 (2003) (Kennedy, J., concurring in part and dissenting in part) ("Cancers caused by asbestos have long periods of latency. Their symptoms do not become manifest for decades after exposure.”); Stonewall Ins. Co. v. Asbestos Claims Mgmt. Corp., 73 F.3d 1178, 1198 (2d Cir. 1995) (“[T]here is a period of time prior to the point at which asbestosis and pleural plaques are clinically diagnosable when the condition is evolving cumulatively or incrementally. This period when the asbestosis or pleural plaques develop undetected is the latency period, which is normally 15 years and may be as long as 40 years. The latency period begins at the time of initial exposure to asbestos and ends with the onset of symptoms and diagnosis. From the time of exposure, asbestos fibers are readily inhaled into the lungs and can immediately injure the cells by causing inflammation and scarring. The disease process for a person who develops asbestosis begins within days of initial exposure to asbestos and continues for decades. How far this disease process progresses depends upon the quantity of asbestos inhaled and deposited in the lungs.”); Borel, 493 F.2d at 1083 (noting the progressive nature of asbestos-related diseases following asbestos exposure); Pack v. Artuz, 348 F. Supp. 2d 63, 79 (S.D.N.Y. 2004) ("Exposure to friable asbestos poses a significant health risk because airborne particles or fibers can become lodged in a person's lungs and in his respiratory tract. Over time this can lead to asbestosis, a nonmalignant scarring of the lungs that causes extreme shortness of breath and often death; lung cancer; gastrointestinal cancer; and mesothelioma, a cancer of the lung lining or abdomen lining that develops as long as thirty years after the first exposure to asbestos and that, once developed, invariably and rapidly causes death.” (citing Envtl. Encapsulating Corp. v. City of New York, 855 F.2d 48, 50 (2d Cir. 1988))). 
Similarly, a typical environmental property damage claim arises as follows: a policyholder operated a manufacturing plant for decades that resulted in the release of contaminants at and around the plant site itself or in waste sites such as landfills. Once the contaminants entered the soil or groundwater, they continuously spread through the soil and groundwater over many years until they were discovered and remediated. $^{8}$ The policyholder then faces liability to a governmental entity or to a private party for the cleanup of the contaminated property. ${ }^{9}$

Thus, two key questions face policyholders, liability insurers, and courts when determining insurers' coverage responsibility for these types of long-tail claims. One, which policy years are implicated or "triggered" by the covered loss? Two, how much of the covered loss should each insurer whose policy has been triggered pay?

\section{Trigger of Coverage}

Courts' answer to the first question — which policy year or years are triggered by the liability-has varied from jurisdiction to jurisdiction. ${ }^{10}$

8. See, e.g., Chem. Leaman Tank Lines, Inc. v. Aetna Cas. \& Sur. Co., 89 F.3d 976, 980-81 (3d Cir. 1995) (noting that contaminants released and spread continuously through groundwater); Cont'l Ins. Cos. v. Ne. Pharm. \& Chem. Co., 842 F.2d 977, 979-80 (8th Cir. 1988) (en banc) (noting that toxic substances may spread through the soil over time following disposal); N. States Power Co. v. Fid. \& Cas. Co. of N.Y., 523 N.W.2d 657, 664 (Minn. 1994) (en banc) (noting that soil and groundwater contamination is a continuous process); Dutton-Lainson Co. v. Cont'l Ins. Co., 778 N.W.2d 433, 445 (Neb. 2010) (finding soil and groundwater contamination from trichloroethylene and trichloroethane was a continuous process following disposal).

9. See, e.g., Ne. Pharm. \& Chem, 842 F.2d at 980; Chem. Leaman, 89 F.3d at 981.

10. Martin J. McMahon, Annotation, Event Triggering Liability Insurance Coverage as Occurring Within Period of Time Covered by Liability Insurance Policy Where Injury or Damage is Delayed-Modern Cases, 14 A.L.R.5th 695, 722 (1993) ("Some courts hold that coverage is triggered continuously throughout the entire time period from exposure to manifestation. Other courts have determined the trigger-of-coverage issue by ascertaining the time of actual damage or injury-in-fact. In some jurisdictions ... the issue appears undecided, at least as a general rule.” (citations omitted)). For a general discussion of coverage triggers in various claim situations, see, for example, Kenneth S. Abraham, Essay, The Rise and Fall of Commercial Liability Insurance, 87 VA. L. REV. 85, 95-96 (2001) (noting the advent of long-tail coverage); Mark W. Dykes, Occurrences, Accidents, and Expectations: A Primer of These (and Some Other) Insurance-Law Concepts, 2003 UTAH L. REV. 831, 838-40 (2003) (discussing policy language and claims used to trigger coverage); James M. Fischer, Insurance Coverage for Mass Exposure Tort Claims: The Debate over the Appropriate Trigger Rule, 45 DRAKE L. REV. 625 (1997) (describing triggers in mass tort litigation claims); Jamie A. Grodsky, Genomics and Toxic Torts: Dismantling the RiskInjury Divide, 59 STAN. L. REV. 1671, 1700-01 (2007) (distinguishing “exposure,” "injury-in-fact," and "exposure in residence" triggers for progressive diseases); Jeffrey W. Stempel, The Insurance Policy as Social Instrument and Social Institution, 51 WM. \& MARY L. REV. 1489, 1563-69 (2010) (discussing asbestos cases and application of the continuous trigger); Nicolas R. Andrea, Comment, Exposure, Manifestation of Loss, Injury-in-Fact, Continuous Trigger: The Insurance Coverage 
Some courts have adopted an "exposure" trigger, which means those insurers whose policies provided coverage at the time of exposure are triggered. ${ }^{11}$ Other courts have adopted an "injury in fact" trigger, which means the liability policies on the risk when the injury actually occurs are triggered. ${ }^{12}$ Other courts have adopted a "manifestation" trigger,

Quagmire, 21 PEPP. L. REV. 813 (1994) (discussing divergent triggering theories); Chandra Lantz, Note, Triggering Coverage of Progressive Property Loss: Preserving the Distinctions Between First- and Third-Party Insurance Cases, 35 WM. \& MARY L. REV. 1801, 1804-05 (1994) (noting triggering rules).

11. See, e.g., Gulf Chem. \& Metallurgical Corp. v. Associated Metals \& Minerals Corp., 1 F.3d 365, 372 (5th Cir. 1993) (apportioning cost of policyholder's defense among insurers on risk and finding that the policyholder must bear its share of defense costs determined by fraction of time it lacked coverage); Cont'l Ins. Cos. v. Ne. Phar. \& Chem. Co., Inc., 811 F.2d 1180, 1189 (8th Cir. 1987) ("Environmental damage occurs at the moment that hazardous wastes are improperly released into the environment[,] and [the] liability policy in effect at the time this damage is caused provides coverage." (footnote omitted)), aff'd in part, 842 F.2d 977 (8th Cir. 1988) (en banc); Clemtex, Inc. v. Se. Fid. Ins. Co., 807 F.2d 1271, 1276 (5th Cir. 1987) (finding that tissue damage takes place upon initial inhalation of asbestos); Hancock Labs., Inc. v. Admiral Ins. Co., 777 F.2d 520, 524 (9th Cir. 1985) ("[T]he California Supreme Court would adopt the exposure theory to determine when bodily injury occurs.”); Commercial Union Ins. Co. v. Sepco Corp., 765 F.2d 1543, 1546 (11th Cir. 1985) (endorsing exposure theory where "it is impossible practically to determine the point at which the fibers actually imbed themselves in the victim's lungs”); Ducre v. Exec. Officers of Halter Marine, Inc., 752 F.2d 976, 992 (5th Cir. 1985) (applying exposure theory to insurance coverage for asbestosis); TBG, Inc. v. Commercial Union Ins. Co., 806 F. Supp. 1444, 1452-53 (N.D. Cal. 1990) (applying exposure trigger theory where each release of the hazardous substance triggered the policy); B.F. Goodrich Co. v. Am. Motorists Ins. Co., No. C84-1224A, 1986 WL 191786, at *12 (N.D. Ohio May 22, 1986) ("The trigger of coverage is the exposure which causes personal injury regardless of the time of the injury.”); Burroughs Wellcome Co. v. Commercial Union Ins. Co., 632 F. Supp. 1213, 1222 (S.D.N.Y. 1986) (holding that insurance duty to defend triggered at ingestion of harmful substance from which such claims arise); Ins. Co. of N. Am. v. Forty-Eight Insulations, Inc., 451 F. Supp. 1230, 1239 (E.D. Mich. 1978) ("[E]ach insurer on the risk when a currently deceased plaintiff was allegedly exposed is obligated to acknowledge coverage and to provide a defense and possibly indemnification.”), aff'd, 633 F.2d 1212 (6th Cir. 1980), clarified, 657 F.2d 814 (6th Cir. 1981); Cole v. Celotex Corp., 599 So. 2d 1058, 1076-77 (La. 1992) (applying exposure trigger).

12. See, e.g., E.R. Squibb \& Sons, Inc. v. Lloyd’s \& Cos., 241 F.3d 154, 166-69 (2d Cir. 2001) (per curiam) (holding that "coverage for [products liability] is triggered at times of actual injury" and that "injury-in-fact can ... include... the inevitable pre-disposition to illness or disability... caused by [the exposure]"); Asbestos Claims Mgmt., 73 F.3d at 1195 (applying the "injury-in-fact" trigger to progressive diseases); Md. Cas. Co. v. W.R. Grace \& Co., 23 F.3d 617, 627 (2d Cir. 1993) ("The actual injury to property-the presence of the asbestos hazard-occurs upon installation and exists regardless of whether it yet has been discovered by the building owners."); Abex Corp. v. Md. Cas. Co., 790 F.2d 119, 122 (D.C. Cir. 1986) (holding that the "insurer's obligation to indemnify ... arises when the asbestos causes real bodily injury during the policy period”); Triangle Publ'ns, Inc. v. Liberty Mut. Ins. Co., 703 F. Supp. 367, 370 (E.D. Pa. 1989) (holding that "an actual injury must occur during the time the policy is in effect in order to be indemnifiable"); Uniroyal, Inc. v. Home Ins. Co., 707 F. Supp. 1368, 1389 (E.D.N.Y. 1988) (finding that injury in fact occurred within approximately two weeks of spraying of Agent Orange); New York v. Amro Realty Corp., 697 F. Supp. 99, 102 n.5 (N.D.N.Y. 1988) (finding that coverage for property damage is triggered when property is “'injured in fact”'), aff'd in part, rev'd in part on other grounds, 936 F.2d 1420 (2d Cir. 1991); Aetna Cas. \& Sur. Co. v. Abbott Labs., Inc., 636 F. Supp. 546, 550 (D. Conn. 1986) (holding that liability coverage is triggered by occurrence of an injury in fact during the policy period); Am. Home Prods. Corp. v. Liberty Mut. Ins. Co., 565 F. Supp. 1485, 1497 (S.D.N.Y. 1983) (holding that 
which means the policies on the risk when the injury or disease manifests - that is, when a medical diagnosis is made or adverse health symptoms first appear-are triggered. ${ }^{13}$ Finally, other courts have adopted a "continuous" trigger, which means all of the policyholder's liability policies on the risk from the time of initial exposure until the injury or disease manifests are triggered. ${ }^{14}$

"to establish ... liability the insured must prove that an 'occurrence'-injury, sickness, or diseasearose during the policy period," but the injury need not manifest during the policy period), aff'd as modified, 748 F.2d 760 (2d Cir. 1984); Armstrong World Indus., Inc. v. Aetna Cas. \& Sur. Co., 52 Cal. Rptr. 2d 690, 703 (Cal. Ct. App. 1996) (endorsing an injury-in-fact analysis); Monsanto Co. v. C.E. Heath Comp. \& Liab. Ins. Co., 652 A.2d 30, 34-35 (Del. 1994) (holding that "[a] policy is activated by bodily injury or property damage that takes place 'during the policy period'”); Cortland Pump \& Equip. Inc. v. Firemen’s Ins. Co. of Newark, 604 N.Y.S.2d 633, 636 (N.Y. App. Div. 1993) (applying an injury-in-fact standard to property damage).

13. See, e.g., Eagle-Picher Indus., Inc. v. Liberty Mut. Ins. Co., 523 F. Supp. 110, 118 (D. Mass. 1981) (applying manifestation trigger), modified, 682 F.2d 12 (1st Cir. 1982).

14. See, e.g., AC\&S, Inc. v. Aetna Cas. \& Sur. Co., 764 F.2d 968, 972 (3d Cir. 1985) (finding "exposure, exposure-in-residence, and manifestation each trigger coverage"); Keene Corp. v. Ins. Co. of N. Am., 667 F.2d 1034, 1041 (D.C. Cir. 1981) ("[E]ach insurer on the risk between the initial exposure and the manifestation of disease is liable to [the insured] for indemnification and defense costs.”); Atchison, Topeka \& Santa Fe Ry. Co. v. Stonewall Ins. Co., No. 94-CV-1464, 1995 WL 854763, at *8 (D. Kan. Sept. 18, 1995) (triggering all CGL policies in force between exposure and manifestation), rev'd on other grounds, No. 75,227, 1997 WL 1048134 (Kan. Jan. 31, 1997); Harleysville Mut. Ins. Co. v. Sussex Cnty., 831 F. Supp. 1111, 1124 (D. Del. 1993) (applying continuous trigger where "it is impossible to identify a precise point in time when property damage occurs from the leaching of pollutants"), aff'd, 46 F.3d 1116 (3d Cir. 1994); Chem. Leaman Tank Lines, Inc. v. Aetna Cas. \& Sur. Co., 817 F. Supp. 1136, 1153 (D.N.J. 1993) (applying continuous trigger theory for environmental claims), aff'd in part \& remanded, 89 F.3d 976 (3d Cir. 1996); Liberty Mut. Ins. Co. v. Triangle Indus., Inc., 765 F. Supp. 881, 885 (N.D. W. Va. 1991) (applying New Jersey law that policies are triggered during the "'continuous period from exposure to the manifestation of damages'” (quoting Gottlieb v. Newark Ins. Co., 570 A.2d 443, 445 (N.J. Super. Ct. App. Div. 1990))), aff'd, 957 F.2d 1153 (4th Cir. 1992); Time Oil Co. v. Cigna Prop. \& Cas. Ins. Co., 743 F. Supp. 1400, 1417 (W.D. Wash. 1990) (noting that Washington has adopted a continuous trigger theory); Broderick Inv. Co. v. Hartford Accident \& Indem. Co., 742 F. Supp. 571, 573 (D. Colo. 1989) (adopting continuous trigger for policies spanning eight years), rev'd on other grounds, 954 F.2d 601 (10th Cir. 1992); New Castle Cnty. v. Cont'l Cas. Co., 725 F. Supp. 800, 812 (D. Del. 1989) (“[A]n entire injurious process may constitute 'injury' under the terms of the policies.”), aff'd in part, rev'd in part sub nom, New Castle Cnty. v. Hartford Accident \& Indem. Co., 933 F.2d 1162 (3d Cir. 1991), abrogated by sub nom., N. Ins. Co. of N.Y. v. Aardvark Assocs., 942 F.2d 189 (3d Cir. 1991); Air Prods. \& Chems., Inc. v. Hartford Accident \& Indem., Co., 707 F. Supp. 762, 768 (E.D. Pa. 1989) (applying continuous trigger of coverage), aff'd in part, vacated in part, 25 F.3d 177 (3d Cir. 1994); Lac D’Amiante du Quebec, Ltee. v. Am. Home Assurance Co., 613 F. Supp. 1549, 1558 (D.N.J. 1985) (construing ambiguous policies in favor of policyholders such that "exposure, exposure in residence, and manifestation each trigger coverage under the policies"), vacated on other grounds, 864 F.2d 1033 (3d Cir. 1988); Montrose Chem. Corp. of Ca. v. Admiral Ins. Co., 913 P.2d 878, 906 (Cal. 1995) (en banc) (applying “continuous injury” trigger); Eli Lilly \& Co. v. Home Ins. Co., 482 N.E.2d 467, 470 (Ind. 1985) (adopting continuous trigger because policyholder "could have reasonably formed an expectation that it was purchasing insurance coverage for all future liability arising from the manufacturing and selling of [a drug with harmful side effects]"); OwensIll., Inc. v. United Ins. Co., 650 A.2d 974, 995 (N.J. 1994) (applying continuous trigger to progressive injury or damage claims); J.H. France Refractories Co. v. Allstate Ins. Co., 626 A.2d 


\section{Allocation}

Similarly, courts' answers to the second question-the amount of liability paid by each triggered policy—also has varied by jurisdiction. ${ }^{15}$ Because long-tail claims may trigger numerous policies, some courts, relying upon the "all sums" language in commercial general liability policies that provides that the insurer agrees to pay "all sums" for which the policyholder is liable, have held that the policyholder can select which of the triggered policy years will cover the liability subject only to the limits of coverage provided by the policies selected. ${ }^{16}$ Other jurisdictions have adopted pro rata allocation, which essentially divides the liability equally among the policy years triggered. ${ }^{17}$ Finally, New

502, 507 (Pa. 1993) (concluding that the policies of each insurer that was on the risk during the development of an asbestosis-related disease are triggered); Wis. Elec. Power Co. v. Cal. Union Ins. Co., 419 N.W.2d 255, 258-59 (Wis. Ct. App. 1987) (finding that the occurrence was active and continuing during the terms of the policies).

15. In "manifestation" trigger jurisdictions, the allocation issue is straightforward because only a single policy year is triggered by each claim. Thus, the loss does not need to be allocated among multiple triggered policy years. For a discussion of insurance allocation law generally, see Jeffrey W. Stempel, Domtar Baby: Misplaced Notions of Equitable Apportionment Create a Thicket of Potential Unfairness for Insurance Policyholders, 25 WM. MitCHELL L. REV. 769, 807-23 (1999). For a discussion of allocation issues in the context of environmental-coverage cases, see Christopher R. Hermann et al., The Unanswered Question of Environmental Insurance Allocation in Oregon Law, 39 Willamette L. ReV. 1131 (2003); Thomas M. Jones \& Jon D. Hurwitz, An Introduction to Insurance Allocation Issues in Multiple-Trigger Cases, 10 VILL. ENVTL. L.J. 25 (1999).

16. See, e.g., AC\&S, 764 F.2d at 974 ("[T]here is no proration of losses under a policy once coverage is triggered.”); Keene Corp., 667 F.2d at 1050 (policyholder may “collect from any insurer whose coverage is triggered, the full amount of indemnity that it is due, subject only to the provisions in the policies that govern the allocation of liability when more than one policy covers an injury”); New Castle, 725 F. Supp. at 817 n.28 (finding insufficient evidence for proration); Reading Co. v. Travelers Indem. Co., No. 87-2021, 1988 WL 13242, at *3 (E.D. Pa. Feb. 18, 1988) (holding each insurer jointly and severally liable for the injuries that occurred during its policy period); Hercules, Inc. v. AIU Ins. Co., 784 A.2d 481, 491 (Del. 2001) (finding “all sums” language in policy to be inconsistent with pro rata allocation); Owens-Ill., 597 F. Supp. at 1524 (holding that once triggered, policy provided coverage without any proration); Owens-Corning Fiberglas Corp. v. Am. Centennial Ins. Co., 660 N.E.2d 770, 788 (Ohio Com. Pl. 1995) (noting that under "continuous injury trigger of coverage," bodily injury occurs from the first exposure to asbestos and ends with diagnosis; and any policy in force may be triggered); J.H. France, 626 A.2d at 506-07 (finding each insurer that issued a CGL policy to manufacturer of asbestos-containing products liable for entire loss subject to policy limits); Am. Nat. Fire Ins. Co. v. B \& L Trucking \& Constr. Co., 951 P.2d 250, 254 (Wash. 1998) (en banc) (holding that all insurers on risk during time of ongoing damage have joint and several obligation to provide coverage of all damages, regardless of amount that occurred during their policy period).

17. See, e.g., Soc'y of the Roman Catholic Church of the Diocese of Lafayette \& Lake Charles, Inc. v. Interstate Fire \& Cas. Co., 26 F.3d 1359, 1367-68 (5th Cir. 1994) (dividing liability for damages based on each insurer's share of coverage); Commercial Union Ins. Co. v. Sepco Corp., 765 F.2d 1543, 1544 (11th Cir. 1985) (requiring all insurers that provided coverage to asbestos manufacturer during periods of exposure to participate in defense and settlement on prorated basis); Ins. Co. of N. Am. v. Forty-Eight Insulations, Inc., 633 F.2d 1212, 1225 (6th Cir. 1980) (holding 
Jersey applies a variation of pro rata allocation that divides the liability among the triggered insurance policies based upon the percentage amount of the limits of each policy issued in relation to all of the insurance triggered by the claim. ${ }^{18}$

\section{E. Non-Cumulation Clauses}

\section{The Wording of Non-Cumulation Clauses}

Adding to the complexity of the analysis are non-cumulation clauses, which often were included in historical liability policies. One common version of the non-cumulation clause, which is used in London umbrella liability policies, contains the following language:

It is agreed that if any loss covered hereunder is also covered in whole or in part under any other excess policy issued to the Assured prior to the inception date hereof the limit of liability hereon... shall be reduced by any amounts due to the Assured on account of such loss under such prior insurance. ${ }^{19}$

In a typical liability-insurance program, many of the policies issued in the program may contain a non-cumulation clause with this language or similar language. ${ }^{20}$

each of manufacturer's insurers issuing policies covering various time periods liable for its pro rata share); Arco Indus. Corp. v. Am. Motorists Ins. Co., 594 N.W.2d 61, 69 (Mich. Ct. App. 1998) (applying time-on-the-risk method of apportioning loss among successive insurers in remediation of chemical contamination claim), modified on reh'g, 594 N.W.2d 74 (Mich. Ct. App. 1998), abrogated by Griswold Props., L.L.C. v. Lexington Ins. Co., 741 N.W.2d 549 (Mich. Ct. App. 2007); N. States Power Co. v. Fid. \& Cas. Co. of N.Y., 523 N.W.2d 657, 658 (Minn. 1994) (en banc) ("Allocation of liability between multiple insurers consecutively on the risk for pollution damages should be proportionate to the damages which occurred during each policy period.”); Cont'l Cas. Co. v. Med. Protective Co., 859 S.W.2d 789, 792 (Mo. Ct. App. 1993) (“[P]roration among the three companies on the basis of the proportionate period of each company's exposure is the fairest method of apportioning the settlement.”).

18. Carter-Wallace, Inc. v. Admiral Ins. Co., 712 A.2d 1116, 1124 (N.J. 1998) (allocating coverage among multiple liability insurers in proportion to the degree of the risks transferred or retained during the years of exposure); see Owens-Ill., 650 A.2d at 995 ("[W]hen progressive indivisible injury or damage results from exposure to injurious conditions for which civil liability may be imposed, courts may reasonably treat the progressive injury or damage as an occurrence within each of the years of a CGL policy.").

19. See, e.g., Stonewall Ins. Co. v. E.I. du Pont de Nemours \& Co., 996 A.2d 1254, 1259 (Del. 2010).

20. See, e.g., Westinghouse Elec. Corp. v. Am. Home Assurance Co., No. A-6706-01T5, A6720-01T5, 2004 WL 1878764, at*19 (N.J. Super. Ct. Law Div. July 8, 2004). 


\section{The Drafting of the London Version of the Non-Cumulation Clause}

The London market version of the non-cumulation clause was first drafted in 1960 by the underwriters at Lloyd's of London in connection with the development of a new umbrella liability form known as the "LRD 60" form. ${ }^{21}$ The LRD 60 form was named after the initials of the principal draftsman, Leslie R. Dew, who was then the chief underwriter for the Merrett Syndicate at Lloyd's of London. ${ }^{22}$ Dew was assisted in the drafting of the LRD 60 form by the then-senior underwriter in the Merrett Syndicate, Henry S. Weavers. ${ }^{23}$

When the LRD 60 form was originally drafted in 1960, it contained two paragraphs worded as follows:

\section{PRIOR INSURANCE AND NON CUMULATION OF LIABILITY}

It is agreed that if any loss covered hereunder is also covered in whole or in part under any other policy issued to the Assured prior to the inception date hereof the limit of liability hereon as stated in item 2 of the Declarations shall be reduced by any amounts due to the Assured on account of such loss under such prior policy insurance.

Subject to the foregoing paragraph and to all the other terms and conditions of this policy in the event that personal injury or property damage arising out of an occurrence covered hereunder is continuing at the time of termination of this policy Underwriters will continue to protect the Assured for liability in respect of such personal injury or property damage without payment of additional premium. ${ }^{24}$

According to at least one London underwriter, the drafters included the non-cumulation clause in the new LRD 60 policy form to prevent a policyholder from obtaining a double recovery on a coverage claim only in the limited circumstance that the policy using the LRD 60 form covered the claim and a prior-incepting policy using a different form also covered the same claim. ${ }^{25}$ The reason for this was that the LRD 60 form,

21. Transcript of Deposition of Peter Wilson at 76, E.I. du Pont de Nemours, 996 A.2d 1254 (No. 523) [hereinafter Wilson Deposition I].

22. Id.

23. Id.

24. See Randolph M. Fields, The Underwriting of Unlimited Risk: The London Market Umbrella Liability Policy 1950 to 1970, Morgan Owen Medal Essay Submission to the Chartered Insurance Institute (1994) (Exhibit 16) (LRD 60 Form Policy, Condition C).

25. See Wilson Deposition I, supra note 21, at 76-81; Transcript of Deposition of Peter Wilson at 65-72 (Sept. 29, 1998), Interlake Corp. v. Certain Underwriters Lloyd's London, No. 2-97-0277 
which was an "occurrence"-based form, significantly changed the standard "accident"-based Price Forbes umbrella liability form that previously had been used by insurers in the London market. ${ }^{26}$ For example, in a situation in which an insured manufactured defective machinery in 1958 that resulted in an injury in 1961, a claim could trigger both a Price Forbes form policy issued in 1958 - when the "accident" of the defective manufacture arguably took place-and a 1961 policy using the LRD 60 form-when the injury arguably "occurred." The drafters designed the non-cumulation clause to thwart the policyholder's attempt at obtaining twice as much coverage as the amount of the liability by pursuing coverage under both policies for the same liability. ${ }^{27}$

Significantly, at the time the non-cumulation clause was drafted in 1960, the drafters did not contemplate the later developments in insurance law that occurred in the United States. ${ }^{28}$ Specifically, concepts such as continuous trigger, in which a single claim can trigger multiple, consecutive policies, and "all sums" allocations, which allows the policyholder to "pick and choose" which policy year would provide coverage for the liability, were unknown and undeveloped in $1960 .^{29}$ Thus, the drafters did not design or intend the non-cumulation clause to apply in the modern-day coverage schemes of continuous trigger and "all sums” coverage responsibility that now exists under state law in jurisdictions such as California, ${ }^{30}$ Delaware, ${ }^{31}$ Illinois, ${ }^{32}$ Indiana, ${ }^{33}$ Massachusetts, ${ }^{34}$ Ohio, ${ }^{35}$ Pennsylvania, ${ }^{36}$ Texas, ${ }^{37}$ Washington, ${ }^{38}$ and

(Ill. App. Ct. Feb. 10, 1998) [hereinafter Wilson Deposition II]; see also Fields, supra note 24, at 34.

26. See Wilson Deposition I, supra note 21, at 76-81.

27. Id. at 158. See also Wilson Deposition II, supra note 25, at 65-72.

28. Wilson Deposition I, supra note 21, at 98-100.

29. Id.

30. See, e.g., Aerojet-Gen. Corp. v. Transp. Indem. Co., 948 P.2d 909, 919-20 \& n.10 (Cal. 1997).

31. See, e.g., Hercules, Inc. v. AIU Ins. Co., 784 A.2d 481, 489-92 (Del. 2001).

32. See, e.g., Zurich Ins. Co. v. Raymark Indus., Inc., 514 N.E.2d 150, 161, 165 (Ill. 1987).

33. See, e.g., Allstate Ins. Co. v. Dana Corp., 759 N.E.2d 1049, 1060, 1063 (Ind. 2001).

34. See, e.g., Mass. Elec. Co. v. Commercial Union Ins. Co., No. 9900467B, 2005 WL 3489874 , at $* 2$ (Mass. Super. Ct. Oct. 25, 2005).

35. See, e.g., Goodyear Tire \& Rubber Co. v. Aetna Cas. \& Sur. Co., 769 N.E.2d 835, 840 (Ohio 2002).

36. See, e.g., J.H. France Refractories Co. v. Allstate Ins. Co., 626 A.2d 502, 505 (Pa. 1993).

37. See, e.g., Am. Physicians Ins. Exch. v. Garcia, 876 S.W.2d 842, 853-54 (Tex. 1994).

38. See, e.g., Am. Nat'l Fire Ins. Co. v. B \& L Trucking \& Constr. Co., 951 P.2d 250, 256-57 (Wash. 1998) (en banc). 
Wisconsin. ${ }^{39}$ Rather, the drafters designed and intended the clause to prevent a policyholder from obtaining a double recovery in very narrow circumstances.

From 1960 until 1970, insurers in the London market used the noncumulation clause in umbrella primary and excess liability policies issued to North American policyholders. ${ }^{40}$ In 1971, insurers in the London market modified the LRD 60 policy form for use in North America, and they designated the modified policy form as the "Umbrella Policy London 1971" form, or the "London "71 umbrella form." ${ }^{41}$ The London "71 umbrella form was prepared by three underwriters in the London market: Peter Wilson, Cliff Richies, and John Byrd. ${ }^{42}$

The London '71 umbrella form incorporated the first paragraph of the non-cumulation clause in the LRD 60 form. ${ }^{43}$ The London '71 umbrella form omitted the second paragraph of the non-cumulation clause from the LRD 60 form because the drafters believed the second paragraph to be redundant of other language in the policy. ${ }^{44}$ Since 1971, London market insurers have issued countless policies using the London '71 umbrella form for North American excess liability policies.

As admitted by one of the drafters of the London "71 umbrella form, the "all sums" allocation scheme-under which the policyholder gets to select the policy year or years that will provide coverage among multiple consecutive policy years that are all liable for a loss - still had not been adopted in 1971 when the non-cumulation clause was modified for the London "71 umbrella form. ${ }^{45}$ Thus, as was the case with the LRD 60 version of the non-cumulation clause, the drafters of the 1971 version also did not intend for the non-cumulation clause to apply in "all sums" allocation jurisdictions.

The non-cumulation clause, as originally drafted in 1960 by insurers in the London market for the LRD 60 form and then modified in the London '71 umbrella form, was used for many years in London umbrella liability policies that were sold to U.S. companies. ${ }^{46}$ Many U.S. insurers

39. See, e.g., Plastics Eng'g Co. v. Liberty Mut. Ins. Co., 759 N.W.2d 613, 625-26 (Wis. 2009).

40. See Wilson Deposition I, supra note 21, at 78 (stating that the LRD 60 form was introduced for umbrella business in May of 1960).

41. See id. at $64,85,87-88$.

42. Id. at 64 .

43. Id. at $84-85$.

44. Id. at 85-86.

45. See id. at 98-100.

46. Id. at $87-88$. 
also issued liability policies in excess of London umbrella policies that "followed-form"- that is, incorporated by reference the policy language of London umbrella liability policies - or issued policies with their own versions of a non-cumulation clause.

\section{THE COURTS' INCONSISTENT INTERPRETATIONS AND APPLICATIONS OF NON-CUMULATION ClAUSES}

In jurisdictions where the courts have interpreted non-cumulation clauses, numerous courts have rejected interpretations of such clauses that would reduce or eliminate the policyholder's recovery. ${ }^{47}$ Yet, the

47. See, e.g., Spartan Iron \& Metal Corp. v. Liberty Ins. Corp., 6 Fed. App’x 176, 179 (4th Cir. 2001) (finding non-cumulation clause ambiguous and construing it against the insurer); Greene, Tweed \& Co. v. Hartford Accident \& Indem. Co., Civil Action No. 03-3637, 2006 WL 1050110, at *16 (E.D. Pa. Apr. 21, 2006) (holding non-cumulation clause to be an invalid and "unenforceable escape clause" because it would have totally abrogated coverage for the policyholder); Glaser v. Hartford Cas. Ins. Co., 364 F. Supp. 2d 529, 538 (D. Md. 2005) (finding ambiguities in the policies and resolving them against the insurer); UTI Corp. v. Fireman’s Fund Ins. Co., 896 F. Supp. 362, 378 (D.N.J. 1995) (invalidating non-cumulation clause as an unenforceable escape clause, stating that "it is 'unacceptable for an insurance company to provide no coverage under a policy for which it received premiums'” (quoting Auto. Underwriters, Inc. v. Fireman's Fund Ins. Co., 874 F.2d 188, 191 (3d Cir. 1989))); A.B.S. Clothing Collection, Inc. v. Home Ins. Co., 41 Cal. Rptr. 2d 166, 17173 (Cal. Ct. App. 1995) (finding that non-cumulation clause is ambiguous); Varian Assocs., Inc. v. Aetna Cas. \& Sur. Co., No. 944196, at 30-31 (Cal. Super. Ct. 1997), in 11-11 Mealey's Litig. REP.: INS. (Jan. 21, 1997) (refusing to enforce a non-cumulation clause that purports "to reduce or eliminate the limits of liability of a policy because of the existence of other insurance covering the same loss" as a disfavored "escape clause"); Hartford Accident \& Indem. Co. v. Emp'rs Ins. of Wausau, No. 847212, 1995 WL 870851, at *21 (Cal. Super. Ct. 1995) (disfavoring application of "prior insurance" clauses that result in no coverage for a loss that the insured reasonably assumed would be covered); In re Asbestos Insurance Coverage Cases, Judicial Council Coordination Proceeding No. 1072, at 30-32 (Cal. Super. Ct. Aug. 29, 1988), in 2:21 MEALEY’s Litig. ReP.: INS. (Sept. 14, 1988) (declining to apply a non-cumulation provision because it was (1) ambiguous; (2) merely another form of "other insurance" clause; and (3) difficult if not impossible to apply in the context of thousands of asbestos-related bodily injury claims); Shemitz Lighting, Inc. v. Hartford Fire Ins. Co., No. CV960052970, 2000 WL 1781840, at *7 (Conn. Super. Ct. Nov. 9, 2000) (finding the policy terms ambiguous and construing them against the insurer); Sherman \& Hemstreet, Inc. v. Cincinnati Ins. Co., 594 S.E.2d 648, 650 (Ga. 2004) (finding the non-cumulation clause ambiguous and construing the ambiguity in favor of the insured); Outboard Marine Corp. v. Liberty Mut. Ins. Co., 670 N.E.2d 740, 750 (Ill. App. Ct. 1996) (finding that "appl[ication of] the 'prior insurance' and 'non cumulation of liability' clauses would give the insurers a double credit and would deprive the insured of the full value of its premium" and would be inequitable "because no excess insurer is concurrently liable with any other”); Spaulding Composites Co. v. Aetna Cas. \& Sur. Co., 819 A.2d 410, 422 (N.J. 2003) ("Once the court turns to pro rata allocation, it makes sense that the noncumulation clause, which would allow the insurer to avoid its fair share of responsibility, drops out of the policy.”); Westinghouse Elec. Corp. v. Am. Home Assurance Co., No. A-6706-01T5, A-672003T5, 2004 WL 1878764, at *21 (N.J. Super. Ct. Law Div. July 8, 2004) (per curiam) (holding noncumulation clauses to be inapplicable because the amounts do not become due until the insured selects the policy year to indemnify it). 
courts' reasoning and rationales for doing so have varied widely in these jurisdictions.

\section{A. Courts in Pro Rata Jurisdictions}

In pro rata jurisdictions, some courts have held that the application of non-cumulation clauses, as requested by certain insurers, would conflict with pro rata allocation. ${ }^{48}$ In short, these courts have reasoned that the insurer's liability already has been reduced because the insurer is only being required to pay a portion of the policyholder's loss. ${ }^{49}$ Thus, it would be inconsistent with such an allocation scheme to further reduce the insurer's liability by giving the insurer an additional "credit" for amounts paid by other insurers. ${ }^{50}$

\section{B. Courts in "All Sums" Jurisdictions}

Similarly, numerous courts in "all sums" jurisdictions have held that a non-cumulation clause should not be construed in a way that eliminates or reduces the policyholder's recovery, but, as discussed below, their reasons for doing so have varied. ${ }^{51}$

1. There Are No Amounts "Due" Under Prior Policies if the Policyholder Does Not Pursue Coverage Under the Prior Policies

Some insurers premise their arguments regarding the application of non-cumulation clauses on the notion that if a policyholder's liabilities span multiple policy periods, then there must be an "amount due" under prior insurance. ${ }^{52}$ This premise is fundamentally incorrect in an "all

48. See Emp'rs Ins. Wausau, 1995 WL 870851, at *21-22 (adopting pro rata allocation and finding that competing other insurance and prior insurance clauses must be resolved in accordance with the terms of the policies); Outboard Marine, 670 N.E.2d at 750 (finding that application of noncumulation clause "would be inequitable because no excess insurer is concurrently liable with any other"); Spaulding, 819 A.2d at 422 ("Once the court turns to pro rata allocation it makes sense that the non-cumulation clause, which would allow the insurer to avoid its fair share of responsibility, drops out of the policy.”).

49. See cases cited supra note 48 .

50. See cases cited supra note 48.

51. See, e.g., Greene, 2006 WL 1050110 at *13-16; UTI Corp., 896 F. Supp. at 378; In re Asbestos Insurance Coverage Cases, No. 1072, at 30-32; Varian, No. 94416, at 30-31.

52. See Westinghouse, 2004 WL 1878764, at *11. 
sums” jurisdiction where the policyholder has selected a single policy year to provide coverage for the liability. Under an ordinary dictionary definition, the word "due" means the amount "owed or owing as a debt." 53 There is no amount "owed" to the policyholder by prior insurance when the policyholder does not present a claim to the prior insurers. Indeed, in "all sums" jurisdictions, the policyholder may choose the policy year for which the insurer is obligated to pay-and thus "owe"-to the policyholder the full amount of the loss subject to policy limits in the chosen policy year. The policyholder has this right even if the policyholder also could have sought to recover the same amount from insurers in other policy years.

The decision in Westinghouse Electric Corp. v. American Home Assurance Co. is particularly instructive on this issue. In Westinghouse, in applying Pennsylvania's "all sums" allocation rule, the court held that a non-cumulation clause was inapplicable to bodily injury claims that spanned multiple policy periods because the policyholder elected to recover for its losses under only one policy year. ${ }^{54}$ Therefore, the court concluded, "there are no 'amounts due' under any prior issued excess policies." ${ }^{55}$ Critical to the court's holding were the facts that (1) under "all sums" allocation, the policyholder's coverage is "spiked" in a single year and (2) although other "policies are theoretically liable, the amounts do not become due until the insured selects the policy year to indemnify it." ${ }^{\text {"5 }}$ Thus, because the policyholder in Westinghouse selected a single policy year to provide coverage, the non-cumulation clause did not apply.

2. Application of the Non-Cumulation Clause as Requested by Insurers Would Allow the Insurers to "Escape” Liability

Some courts have found non-cumulation clauses to be unenforceable because, as interpreted by the insurers, they were similar to "other insurance" clauses that allowed the insurers to "escape" liability for a loss to the detriment of the policyholders. ${ }^{57}$ Where all triggered policies in all triggered years have provisions which purport to deflect coverage responsibility to another year, courts have concluded that these

\footnotetext{
53. MERRIAM-WEBSTER's COLLEGIATE DiCTIONARY 357 (10th ed. 1997).

54. Westinghouse, $2004 \mathrm{WL} 1878764$, at *21.

55. Id.

56. Id.

57. See cases cited supra note 48 .
} 
provisions cancel out each other. ${ }^{58}$ Thus, such courts have not allowed the clauses to defeat recovery by the policyholder. ${ }^{59}$

As recognized by courts in "all sums" jurisdictions, the ability of the policyholder to select which policy year initially will respond to the loss would be illusory if clauses in those policies that purport to shift liability to another insurer were permitted to operate to the detriment of the policyholder. ${ }^{60}$

\section{Some Courts Have Applied Non-Cumulation Clauses to Reduce, but Not Eliminate, the Insurer's Payment Obligations}

Some courts have applied non-cumulation clauses to reduce policy limits where the long-tail liabilities were covered under multiple policy

58. See, e.g., Underwriters at Lloyd's, London v. Pike, 977 F.2d 1278, 1279-80 (8th Cir. 1992) (concluding that both insurers' escape clauses "are mutually repugnant and both policies will share pro rata liability”); Horace Mann Ins. Co. v. United Int’l Ins. Co., 762 F. Supp. 1470, 1474 (M.D. Ala. 1990) (finding two policies with excess insurance clauses mutually repugnant because two policies cannot be excess to each other); Liberty Mut. Ins. Co. v. Pac. Indem. Co., 579 F. Supp. 140, 143 (W.D. Pa. 1984) (finding that conflicting excess clauses cancel each other out and prorating each insurer's liability according to the policy limit); State Farm Mut. Auto. Ins. Co. v. Gen. Mut. Ins. Co., 210 So. 2d 688, 694-95 (Ala. 1968) (per curiam) (finding that “excess insurance” clauses were mutually repugnant and prorating the payout by policy limits); Empire Cas. Co. v. St. Paul Fire \& Marine Ins. Co., 764 P.2d 1191, 1199 (Colo. 1988) (en banc) (voiding mutually repugnant "other insurance” clauses); Buckson v. Pa. Nat’l Mut. Cas. Ins. Co., C.A. No. 97C-04-009, 1999 Del. Super. LEXIS 301, at*13-16 (Del. Super. Ct. Mar. 15, 1999) (finding competing policies' "other insurance" provisions to be "mutually repugnant" and prorating loss based on policy limits); Celina Mut. Cas. Co. of Ohio v. Citizens Cas. Co. of N.Y., 71 A.2d 20, 22 (Md. Ct. App. 1950) ("The general rule as to insurance policies is that where there are pro rata or proportionate clauses in several insurance policies insuring the same property, the insurance is concurrent and each insurer is liable for its proportionate amount.”); Rogers v. Snappy Car Rental Inc., 639 A.2d 1154, 1160 (N.J. Super. Ct. Law Div. 1993) (finding clauses in both policies are mutually repugnant); Lamb-Weston, Inc. v. Or. Auto. Ins. Co., 341 P.2d 110, 119 (Or. 1959) (finding that where any policy comes in conflict with the "other insurance" clause of another insurer, they are repugnant and should be rejected "in toto").

59. See cases cited supra note 58 .

60. See, e.g., Koppers Co. v. Aetna Cas. \& Sur. Co., 98 F.3d 1440, 1454 (3d Cir. 1996) (finding that under "all sums" allocation, an "other insurance" clause does not prohibit the policyholder from selecting the policy to respond, but rather permits an insurer to seek contribution from other insurers); Keene Corp. v. Ins. Co. of N. Am., 667 F.2d 1034, 1050 (D.C. Cir. 1981) (holding that "other insurance" does not diminish the primary duty of the insurer whose coverage is triggered to indemnify the policyholder in full); Aerojet-Gen. Corp. v. Transport Indem. Co., 948 P.2d 909, 92733 (Cal. 1997) (holding that "other insurance" clauses were without effect under "all sums" scheme); Owens-Corning Fiberglas Corp. v. Am. Centennial Ins. Co., 660 N.E.2d 770, $794-95$ (Ohio Ct. Com. Pl. 1995) (holding that an insurer in an "all sums" scheme must provide coverage for the insured's entire liability notwithstanding an "other insurance" provision); J.H. France Refractories Co. v. Allstate Ins. Co., 626 A.2d 502, 508-09 (Pa. 1993) (finding that the "other insurance" provision at issue allowed the insurer to seek indemnification from other insurers but did not reduce amount owed to insured under the "all sum" scheme). 
years. ${ }^{61}$ Such courts typically have done so where a single insurer issues policies in multiple years, and the court determines that the insurer should not have to pay for the same loss multiple times. ${ }^{62}$ For example, in Treesdale, the non-cumulation clause at issue read as follows:

If the same occurrence gives rise to personal injury, property damage or advertising injury or damage which occurs partly before and partly within any annual period of this policy, each occurrence limit and the applicable aggregate limit or limits of the policy shall be reduced by the amount of each payment made by the company with respect to each occurrence, either under a previous policy or policies of which this policy is a replacement, or under this policy with respect to previous annual periods thereof. ${ }^{63}$

The policyholder did not contend the clause was ambiguous. ${ }^{64}$ Consequently, in applying the clause, the court decided that the insurer

61. See, e.g., Liberty Mut. Ins. Co. v. Treesdale, Inc., 418 F.3d 330, 339-45 (3d Cir. 2005) (noting that a non-cumulation clause does not eliminate coverage, but "provides that if a single occurrence gives rise to an injury during more tha[n] one policy period, only one occurrence limit will apply”); Plantation Pipeline Co. v. Cont'l Cas. Co., No. 1:03-CV-2811-WBH, 2008 U.S. Dist. LEXIS 80680, at *9-13 (N.D. Ga. July 8, 2008) (enforcing non-cumulation clause); Liberty Mut. Ins. Co. v. Black \& Decker Corp., 383 F. Supp. 2d 200, 216 (D. Mass. 2004) (dictum) (noting that the non-cumulation clause "appears unambiguous and enforceable, and eminently sensible besides"); Cal. Ins. Co. v. Stimson Lumber Co., No. 01-514-HA, 2004 U.S. Dist. LEXIS 10098, at*32 (D. Or. May 26, 2004) (concluding that the non-cumulation provision applies to reduce the insurer's policy limits by the amounts paid in prior policy years or the amounts paid by other excess settling insurers where there is any excess insurance coverage available), aff'd in part, rev'd in part 325 F. App'x 496 (9th Cir. 2009); Endicott Johnson Corp. v. Liberty Mut. Ins. Co., 928 F. Supp. 176, 181-82 (N.D.N.Y. 1996) (finding that the non-cumulation clause prevented the insured from recovering more than one policy limit after invoking coverage under several policies); O-I Brockway Glass Container, Inc. v. Liberty Mut. Ins. Co., No. Civ. 90-2797(AET), 1994 WL 910935, at *3 (D.N.J. Feb. 10, 1994) (stating that " $[\mathrm{t}]$ he Non-Cumulation Clause in both content and title clearly states that the insured shall not recover more than the per occurrence limit by invoking coverage under several policies”); Air Prods. \& Chems., Inc. v. Hartford Accident \& Indem. Co., CIV.A. No. 86-7501, 1989 WL 73656, at $* 1$ (E.D. Pa. June 30, 1989) (holding that the non-cumulation clause allowed the insurer was entitled to reduce the policy's limits by the amount of payment under earlier policy), aff'd in part, vacated in part on other grounds, 25 F.3d 177 (3d Cir. 1994); Viking Pump, Inc. v. Century Indem. Co., No. 1465-VCS, 2009 WL 3297559, at *28-29 (Del. Ch. Oct. 14, 2009) (finding that the prior insurance clause prevents a policyholder from obtaining more than one year's set of per-occurrence limits for a given occurrence); Hiraldo v. Allstate Ins. Co., 840 N.E.2d 563, 564 (N.Y. 2005) (noting that the non-cumulation clause resulted in the "intuitive[e]" outcome that an insurer's total liability for a single loss is reduced to one limit).

62. See, e.g., Air Prods., 1989 WL 73656, at*1.

63. Treesdale, 418 F.3d at 339 (emphasis added); see also Greene, Tweed \& Co. v. Hartford Accident \& Indem. Co., Civil Action No. 03-3637, 2006 WL 1050110, at *17 (E.D. Pa. Apr. 21, 2006) (distinguishing Treesdale because it dealt with a clause "that appear[ed] in multiple policies issued by the same insurer that cover[ed] the same loss").

64. Treesdale, 418 F.3d at 344. 
should only be required to pay for the loss under one of the policies it issued. $^{65}$

Courts have shown a greater willingness to interpret the version of the non-cumulation clause at issue in the Treesdale case to the detriment of the policyholder because, in several ways, the language at issue in that case was narrowly tailored and had a much smaller scope than the typical non-cumulation clause language. Moreover, the non-cumulation clause language in Treesdale was clearly triggered by prior payment rather than by the amorphous phrase "any amounts due to the Assured" found in the London market version of the non-cumulation clause language. ${ }^{66}$

Further, rather than purporting to effectuate an automatic reduction in policy limits whenever any prior excess policy of any other insurer may owe obligations to the policyholder-as some insurers contend the clause should operate ${ }^{67}$ - the language found in such cases only reduced a policy's limits when the "company," that is, the same insurer, made payments under one of its own prior policies. ${ }^{68}$ Thus, the noncumulation clause at issue in cases such as Treesdale does not purport to change the insurer's coverage obligations by virtue of another insurer's liability.

Tellingly, nearly all of the judicial decisions relied upon by insurers to support their coverage-reducing or coverage-eliminating interpretation of non-cumulation clauses contain policy language similar to, if not exactly the same as, that at issue in the Treesdale case. ${ }^{69}$ Further, all of

65. Id. at 345 .

66. Compare id. at 339 ("[The] limits of the policy shall be reduced by the amount of each payment....” (emphasis added)), with Stonewall Ins. Co. v. E.I. du Pont de Nemours \& Co., 996 A.2d 1254, 1259 (Del. 2010) ("[The policy limits] shall be reduced by any amounts due to the Assured on account of such loss under such prior insurance.” (emphasis added)); see supra Part II.E.2.

67. See E.I. du Pont de Nemours, 996 A.2d at 1259 (describing insurer's contention that the non-cumulation clause unambiguously operated to reduce insurer's liability).

68. See, e.g., Treesdale, 418 F.3d at 339 ("[The] limits of the policy shall be reduced by the amount of each payment made by the company... either under a previous policy or policies of which this policy is a replacement ...." (emphasis added)).

69. See, e.g., Liberty Mut. Ins. Co. v. Black \& Decker Corp., 383 F. Supp. 2d 200, 216 (D. Mass. 2004); Endicott Johnson Corp. v. Liberty Mut. Ins. Co., 928 F. Supp. 176, 179-80 (N.D.N.Y. 1996); O-I Brockway Glass Container, Inc. v. Liberty Mut. Ins. Co., No. Civ. 90-2797(AET), 1994 WL 910935, at*1 (D.N.J. Feb. 10, 1994); Air Prods. \& Chems., Inc. v. Hartford Accident \& Indem. Co., CIV.A. No. 86-7501, 1989 WL 73656, at*1 n.2 (E.D. Pa. June 30, 1989). See also Reliance Ins. Co. v. Treasure Coast Travel Agency, Inc., 660 So. 2d 1136, 1137 (Fla. Dist. Ct. App. 1995) (involving multiple, successive policies issued by the same insurer, all of which included a noncumulation clause that provided "[r]egardless of the number of years this insurance remains in force ... no Limit of Insurance cumulates from year to year or period to period”); Hiraldo ex rel. Hiraldo v. Allstate Ins. Co., 840 N.E.2d 563, 564 (N.Y. 2005) (involving multiple, successive 
these cases involved one insurer that had issued successive policies that contained the same non-cumulation clause. ${ }^{70}$

Essentially, these courts have held that the non-cumulation clauses were "valid so long as the insurer invoking the provision will be required to indemnify the insured pursuant to either the policy containing the provision or under other policies it issued to the insured." ${ }^{\text {"1 }}$ Indeed, in such decisions, the insurer in whose favor a non-cumulation clause was interpreted had paid the policyholder the full limits of at least one of its policies. $^{72}$

\section{THE PRINCIPLES OF INSURANCE POLICY INTERPRETATION RELEVANT TO THE INTERPRETATION OF NON-CUMULATION CLAUSES}

When courts interpret and apply policy language such as noncumulation clauses, three well-established rules of policy interpretation emerge as particularly relevant to the analysis: (1) the doctrine of contra proferentem, (2) the doctrine of "reasonable expectations," and (3) the construction of the policy as a whole.

\section{A. The Doctrine of Contra Proferentem}

It is hornbook insurance law that because insurers are the drafters of policy language such as non-cumulation clauses, the doctrine of contra proferentem $^{73}$ applies, which means any ambiguities in the policy

policies issued by the same insurer, all of which included a non-cumulation clause that provided "[r]egardless of the number of ... policies involved, our total liability ... for damages resulting from one loss will not exceed the limit of liability for Coverage X shown on the declarations page”); Mark IV Indus., Inc. v. Lumbermens Mut. Cas. Co., No. 2005/2029, 2006 WL 1458245, at*1 (N.Y. Sup. Ct. Apr. 28, 2006) (involving multiple, successive policies issued by the same insurer, all of which included a non-cumulation clause that provided "[i]f one occurrence causes bodily injury, personal injury and/or property damage during this policy period AND during the policy period of one or more prior and/or future policy(ies)... issued to you by us, then this policy's Each Occurrence Limit will be reduced by the amount of each payment made by us").

70. See cases cited supra note 69.

71. Greene, Tweed \& Co. v. Hartford Accident \& Indem. Co., Civil Action No. 03-3637, 2006 WL 1050110, at *19 (E.D. Pa. Apr. 21, 2006).

72. See, e.g., id. at *1.

73. For a discussion of insurance policy interpretation and the doctrine of contra proferentem, see generally Kenneth S. Abraham, A Theory of Insurance Policy Interpretation, 95 MicH. L. REV. 531 (1996) and David Horton, Flipping the Script: Contra Proferentem and Standard Form Contracts, 80 U. COLO. L. REV. 431 (2009) (detailing the history of contra proferentem and claiming a decline in strict application of the doctrine). 
language should be construed against the insurers and in favor of coverage. ${ }^{74}$ The test under many states' laws for determining whether

74. See, e.g., 13 John Alan ApPleman \& JeAn ApPleman, InSURANCE LAW AND PRACTiCe, $\S \S 7401,7481$ (1976 \& Supp. 1995); 1 ARTHUR N. BROOK ET AL., BUSINESS INSURANCE LAW AND Practice Guide § 2.02[1] (1992); 4 ROWLAND H. LONG, THE LAW OF Liability INSURANCE $\S \S 16.04,16.06$ (1999); BARRY R. OSTRAGER \& THOMAS R. NEWMAN, HANDBOOK ON INSURANCE COVERAge Disputes § 1.03[b][1] (3d ed. 1990); 2 LeE R. RusS \& THOMAS F. SEgalla, Couch ON INSURANCE § 22:14 (3d. ed. 1997); JEFFREY W. STEMPEL, INTERPRETATION OF INSURANCE Contracts §§ 5.1, 5.2 (1994); David B. Goodwin, Disputing Insurance Coverage Disputes, 43 StAN. L. REV. 779, 795 (1991). Much case law recognizes and applies contra proferentem. See, e.g., New Castle Cnty., Del. v. Nat'l Union Fire Ins. Co. of Pittsburgh, Pa., 243 F.3d 744, 750 (3d Cir. 2001) ("When policy language is ambiguous ... under Delaware law this Court must apply the doctrine of contra proferentem.”); Kunin v. Benefit Trust Life Ins. Co., 910 F.2d 534, 538-39 (9th Cir. 1990) ("According to the law of California and, indeed, every other state as well as the District of Columbia, ambiguities in insurance contracts must be construed against the insurer." (footnotes omitted)); Keller v. Safeco Ins. Co. of Am., 877 S.W.2d 90, 92 (Ark. 1994) ("If there is a reasonable construction that may be given to the contract that would justify recovery, it is the duty of the court to adopt it.”); Crane v. State Farm Fire \& Cas. Co., 485 P.2d 1129, 1130 (Cal. 1971) (en banc) ("Any ambiguity or uncertainty in an insurance policy is to be resolved against the insurer."); Hecla Mining Co. v. N.H. Ins. Co., 811 P.2d 1083, 1091-92 (Colo. 1991) (en banc) (finding the term "sudden" to be ambiguous and construing the phrase "sudden and accidental" against the insurer to mean unexpected and unintended); Cody v. Remington Elec. Shavers, 427 A.2d 810, 812 (Conn. 1980) (stating that ambiguities in contract documents are to be resolved against the party responsible for its drafting); Phillips Home Builders, Inc. v. Travelers Ins. Co., 700 A.2d 127, 129-30 (Del. 1997) (en banc) ("If there is an ambiguity, however, the contract language is 'construed most strongly against the insurance company that drafted it.”' (quoting Rhone-Poulenc Basic Chems. Co. v. Am. Motorists Ins. Co., 616 A.2d 1192, 1196 (Del. 1992))); Crawford v. Prudential Ins. Co. of Am., 783 P.2d 900, 904 (Kan. 1989) ("Since an insurer prepares its own contracts, it has a duty to make the meaning clear, and if it fails to do so, the insurer, and not the insured, must suffer." (quoting Fowler v. United Equitable Ins. Co. 438 P.2d 46, 48 (Kan. 1968))); RPM Pizza, Inc. v. Auto. Cas. Ins. Co., 601 So. 2d 1366, 1369 (La. 1992) (“[A]ny ambiguity must be construed against the insurance company and in favor of the reasonable construction that affords coverage."); Me. Drilling \& Blasting, Inc. v. Ins. Co. of N. Am., 665 A.2d 671, 673 (Me. 1995) (“A liability insurance policy must be construed to resolve all ambiguities in favor of coverage.”); Am. Bumper \& Mfg. Co. v. Hartford Fire Ins. Co., 550 N.W.2d 475, 480 (Mich. 1996) (“[I]n construing insurance contracts, any ambiguities are strictly construed against the insurer to maximize coverage.”); DeBerry v. Am. Motorists Ins. Co., 236 S.E.2d 380, 382 (N.C. Ct. App. 1977) (“[A]ny ambiguity or uncertainty as to the meaning of terms in a policy should be resolved against the insurer since it selected the language used.”); Kief Farmers Coop Elevator Co. v. Farmland Mut. Ins. Co., 534 N.W.2d 28, 32 (N.D. 1995) (noting that courts should "balance the equities in favor of providing coverage to the insured" when construing ambiguous policy language); Weaver v. Royal Ins. Co. of Am., 674 A.2d 975, 977 (N.H. 1996) ("If the policy language is ambiguous or where conflicting interpretations exist, [the court will] construe the [insurance] policy in favor of providing coverage to insured.”); Ohio Cas. Ins. Co. v. Flanagin, 210 A.2d 221, 226 (N.J. 1965) (“'If the controlling language will support two meanings, one favorable to the insurer, and the other favorable to the insured, the interpretation sustaining coverage must be applied."” (quoting Mazzilli v. Accident \& Cas. Ins. Co. of Winterthur, 170 A.2d 800, 803 (N.J. 1961))); New York v. Home Indem. Co., 486 N.E.2d 827, 829 (N.Y. 1985) (“If . . . the language in the insurance contract is ambiguous and susceptible of two reasonable interpretations, the parties may submit extrinsic evidence as an aid in construction, and the resolution of the ambiguity is for the trier of fact.”); Gomolka v. State Auto. Mut. Ins. Co., 436 N.E.2d 1347, 1348-49 (Ohio 1982) ("Policies of insurance, which are in language selected by the insurer and which are reasonably open to different interpretations, will be construed most favorably for the 
policy language is ambiguous is whether the provisions at issue are reasonably or fairly susceptible to different interpretations or meanings. ${ }^{75}$ Where the controversy involves a phrase that insurance companies have failed to define and has generated many lawsuits with varying results, common sense dictates that the policy language must be ambiguous. ${ }^{76}$

insured.”); Cohen v. Erie Indem. Co., 432 A.2d 596, 599 (Pa. Super. Ct. 1981) (“The very existence of two contrary schools of thought evidenced by the conflicting holdings in cases cited by both the Appellee and the Appellant is convincing in the conclusion that the clause in issue is ambiguous as to whether coverage is to be afforded under the fact situation presented. Such ambiguity, by itself, requires that we resolve the issue in favor of the Appellee, the insured driver.”); Nat'l Union Fire Ins. Co. of Pittsburgh, Pa. v. Hudson Energy Co., 811 S.W.2d 552, 555 (Tex. 1991) (“[I]f a contract of insurance is susceptible of more than one reasonable interpretation, we must resolve the uncertainty by adopting the construction that most favors the insured."); Garneau v. Curtis \& Bedell, Inc., 610 A.2d 132, 134 (Vt. 1992) ("In determining whether the insurer has a duty to indemnify, any ambiguity in the insurance contract will be resolved in favor of the insured."); Murray v. W. Pac. Ins. Co., 472 P.2d 611, 615 (Wash. Ct. App. 1970) (“[E]xclusionary clauses in insurance policies are construed most strongly against the insurer.").

75. 13 APPLEMAN \& APPLEMAN, supra note 74, § 7403 (noting that the insurer has the burden of establishing that insurer's interpretation is the only fair interpretation of the contract); 4 LONG, supra note 74, § 16.06. Ample case law supports this rule. See, e.g., New Castle, 243 F.3d at 750 ("'The settled test for ambiguity is whether the provisions in controversy are reasonably or fairly susceptible of different interpretations or may have two or more different meanings.'” (quoting New Castle Cnty. v. Nat'l Union Fire Ins. Co., 174 F.3d 338, 342-44 (3d Cir. 1999))); W. Heritage Ins. Co. v. Magic Years Learning Ctrs. \& Child Care, Inc., 45 F.3d 85, 88 (5th Cir. 1995) (noting that Texas law enforces policy as written if it can be given only one reasonable construction); Vargas $\mathrm{v}$. Ins. Co. of N. Am., 651 F.2d 838, 840 (2d Cir. 1981) (noting that the insurer bears the heavy burden of proving the policyholder's interpretation is unreasonable and the insurer's interpretation is the only one that could fairly be placed on the policy); Desai v. Farmers Ins. Exch., 55 Cal. Rptr. 2d 276, 280 (Cal. Ct. App. 1996) (finding that policy language is ambiguous if it is susceptible to two or more meanings); Phillips Home Builders, Inc. v. Travelers Ins. Co., 700 A.2d 127, 130 (Del. 1997) (en banc) ("'Convoluted or confusing terms are the problem of the insurer ... not the insured.”" (quoting Penn Mut. Life Ins. Co. v. Oglesby, 695 A.2d 1146, 1150 (Del. 1997))); High Country Assocs. v. N.H. Ins. Co., 648 A.2d 474, 476 (N.H. 1994) ("If the language of the policy reasonably may be interpreted more than one way and one interpretation favors coverage, an ambiguity exists in the policy that will be construed in favor of the insured and against the insurer.”); Salem Grp. v. Oliver, 607 A.2d 138, 139 (N.J. 1992) (per curiam) ("When a policy fairly supports an interpretation favorable to both the insured and the insurer, the policy should be interpreted in favor of the insured.”); Harris, Jolliff \& Michel, Inc. v. Motorists Mut. Ins. Co., 255 N.E.2d 302, 305-07 (Ohio Ct. App. 1970) (finding that where insurer and insured each presented reasonable interpretations of exclusion, exclusion is ambiguous and must be interpreted in favor of the insured); Bartlett v. Amica Mut. Ins. Co., 593 A.2d 45, 47 (R.I. 1991) (noting that a contract will be strictly construed in favor of the insured when the language is ambiguous or capable of more than one reasonable meaning); Bonner v. United Servs. Auto. Ass'n, 841 S.W.2d 504, 506 (Tex. Ct. App. 1992) (“The court must adopt the construction of an exclusionary clause urged by the insured as long as that construction is not unreasonable, even if the construction urged by the insurer appears to be more reasonable or a more accurate reflection of the parties' intent.").

76. See, e.g., New Castle Cnty., 243 F.3d at 755-56 (finding ambiguity where the contested phrase was not defined and had been interpreted differently by various courts); Sec. Ins. Co. of Hartford v. Investors Diversified Ltd., 407 So. 2d 314, 316 (Fla. Dist. Ct. App. 1981) ("The insurance company contends that the language is not ambiguous, but we cannot agree and offer as proof of that pudding the fact that the Supreme Court of California and the Fifth Circuit in New Orleans have arrived at opposite conclusions from a study of essentially the same language.”); 
As discussed above, an ambiguous insurance policy provision is one that has more than one reasonable meaning. When one attempts to apply non-cumulation clauses to long-tail liability claims, it becomes apparent that the language in many non-cumulation clauses is riddled with ambiguities and unanswered questions regarding how it should apply.

To focus the discussion, consider again the language of the London version of the non-cumulation clause:

It is agreed that if any loss covered hereunder is also covered in whole or in part under any other excess policy issued to the Assured prior to the inception date hereof the limit of liability hereon... shall be reduced by any amounts due to the Assured on account of such loss under such prior insurance. ${ }^{77}$

Even the basic part of the clause- "if any loss covered hereunder is also covered in whole or in part under any other excess policy issued to the Assured prior to the inception date hereof ${ }^{\text {"78 }}$-is unclear. How does one determine if a loss is "covered" under a prior-incepting policy? Must there be a court judgment stating as such? Though it is unlikely to happen, must there be an admission of coverage by the prior insurers? Need there be only an assertion of the prior insurer's coverage responsibility by the subsequent insurer? In long-tail liability cases in "all sums" jurisdictions, the liabilities are covered by the policies in whatever year the policyholder has selected to cover them. ${ }^{79}$ Necessarily, therefore, these same liabilities are not "covered" by policies in prior years because the policyholder has not selected those

Crawford, 783 P.2d at 908 ("[T] Appeals reached different conclusions and the justices of this court do not agree on the proper interpretation. Under such circumstances, the clause is, by definition, ambiguous and must be interpreted in favor of the insured.”); Allstate Ins. Co. v. Hartford Accident \& Indem. Co., 311 S.W.2d 41, 47 (Mo. Ct. App. 1958) ("Since we assume that all courts adopt a reasonable construction, the conflict is of itself indicative that the word as so used is susceptible of at least two reasonable interpretations, one of which extends the coverage to the situation at hand.”); George H. Olmsted \& Co. v. Metro. Life Ins. Co., 161 N.E. 276, 277-78 (Ohio 1928) (“[T]he fact that [other jurisdictions have reached conflicting interpretations], coupled with the fact that the lower courts in the instant case are in disagreement...., presents [a] persuasive argument of the ambiguity of the clause ....”); Cohen, 432 A.2d at 599 ("The mere fact that [courts differ on the construction of the provision] itself creates the inescapable conclusion that the provision in issue is susceptible to more than one interpretation.”). See also 1 BROOK ET AL., supra note 74, §§ 2.02[1], 5.8; 4 LONG, supra note 74, § 16.06; Charles C. Marvel, Annotation, Division of Opinion Among Judges on Same Court or Among Other Courts or Jurisdictions Considering Same Question, as Evidence that Particular Clause of Insurance Policy is Ambiguous, 4 A.L.R.4th 1253 (1981).

77. See Stonewall Ins. Co. v. E.I. du Pont de Nemours \& Co., 996 A.2d 1254, 1259 (Del. 2010).

78. Id. (emphasis added).

79. See supra Part III.B. 
prior policy years for coverage. Thus, the liabilities are not covered by both the policies in the selected year and the policies in the prior years.

Moreover, the clause states that "the limit of liability hereon ... shall be reduced by any amounts due to the Assured on account of such loss under such prior insurance." 80 What constitutes an amount "due" under prior insurance? Is it an amount that a court adjudged was due? Is it an amount that the subsequent insurer alleges is due from the prior-year insurer? Is it an amount that the prior insurer acknowledges is due? Is it an amount actually paid by a prior insurer on the same loss? Again, given that the policyholder can choose the policy year that should cover its liabilities in an "all sums" jurisdiction, ${ }^{81}$ an insurer's contention that the same amounts are "due” under prior policies makes no sense.

What about due process? If one were to accept the insurer's argument, it very well could be determined that amounts are due from prior-incepting policies even though the insurers that issued the policies are not even parties to the case. Such a result arguably would not even be enforceable against the insurers that issued prior-incepting policies under the well-established rule of law that a judgment cannot be entered against a party that was not a party in the case. ${ }^{82}$

What happens if the policyholder has settled with prior insurers even though the settling insurers denied any obligation to pay for the liabilities and continued to deny such liability in the settlement agreements themselves? Surely, the payments made by such insurers cannot be viewed as having been due when the settling insurers continue to contend they owed nothing but settled for business reasons.

Additionally, what does it mean that the limits are "reduced"? For example, are the limits of the policy reduced for just the loss at issue but

80. E.I. du Pont de Nemours, 996 A.2d at 1259 (emphasis added).

81. See supra Part III.B.

82. See, e.g., Taylor v. Sturgell, 553 U.S. 880, 884 (2008) (“"[O]ne is not bound by a judgment in personam in a litigation in which he is not designated as a party or to which he has not been made a party by service of process.”” (quoting Hansberry v. Lee, 311 U.S. 32, 40 (1940))); Martin v. Wilks, 490 U.S. 755, 762 (1989) (“A judgment or decree among parties to a lawsuit resolves issues as among them, but it does not conclude the rights of strangers to those proceedings.”), superseded by statute, Civil Rights Act of 1991, Pub. L. No. 102-106, § 108, 105 Stat. 1071, 1076-77, as recognized in Landsgraf v. USI Film Prods. 511 U.S. 244 (1994); EEOC v. Pemco Aeroplex, Inc., 383 F.3d 1280, 1286 (11th Cir. 2004) (“This Circuit's preclusion standards reflect the longstanding and deep-rooted principle of American law that a party cannot be bound by a judgment in a prior suit in which it was neither a party nor in privity with a party.”); Mason v. Genisco Tech. Corp., 960 F.2d 849, 851 (9th Cir. 1992) ("A person is not bound by a judgment in a litigation to which he or she has not been made a party by service of process.”); Madison Square Garden Boxing, Inc. v. Shavers, 562 F.2d 141, 143-44 (2d Cir. 1977) ("[I]t is the general rule that no one can be bound by a judgment in litigation in which he or his privy was not a party.”). 
then reinstated for the next loss? Or are the limits reduced for all future losses as well?

In E.I. du Pont de Nemours, ${ }^{83}$ for example, one of the insurer's experts contended the limits of the policy were reduced for just the liability at issue, but another expert of the insurer contended the limits were forever reduced for all future liabilities and for all types of claims. ${ }^{84}$ Thus, in the second expert's opinion, because amounts were due under prior policies issued by other insurers, the insurer's policy at issue was relieved of all coverage obligations for all types of claims even though the insurer had never paid a dime under the policy for any type of claim. $^{85}$ Such an outcome would be incredible and completely inconsistent with insurance law. Moreover, if an insurer's own "experts" do not agree on how the policy should work, how can the insurer credibly argue the policy language is unambiguous?

Another unanswered question is how does the "reduction of limits" language apply when multiple policies in the same policy year all contain the same non-cumulation clause? Which policies in that year receive the benefit of the reduction of limits, and which ones do not? For example, in the E.I. du Pont de Nemours case, the insurer argued that the lowest four layers of coverage in its policy year should have their limits reduced down to zero, but the two highest layers of coverage in that year must cover the policyholder's claim. ${ }^{86}$ Where is it written in the clause, or elsewhere, that the lowest layers of coverage should have their limits reduced, but the higher layers should not? Indeed, such a result would be in conflict with language typically found in excess policies that requires exhaustion of the lower-layer policies before triggering the higher-layer policies. $^{87}$

83. 996 A.2d at 1259.

84. See Wilson Deposition I, supra note 21, at 27-28.

85. See id. at 28.

86. 996 A.2d at $1259-60$.

87. See, e.g., 15 LeE R. Russ \& ThOMAs F. SEgalla, COUCH ON INSURANCE § 220:32 (3d ed. 1999) ("The purpose of ... excess... coverage is to protect the insured in the event of a catastrophic loss in which liability exceeds the available primary coverage. Accordingly, it is only after the underlying primary policy has been exhausted does the excess ... coverage kick in.” (footnote omitted)); Marcy Louise Kahn, The "Other Insurance” Clause, 19 FoRUM 591, 604 (1984) ("[W]hen a loss exceeds the amount of a primary policy[, it] triggers coverage under an excess policy....”). Courts have widely recognized this function of excess coverage. See, e.g., Horace Mann Ins. Co. v. Gen. Star Nat’l Ins. Co., 514 F.3d 327, 329 (4th Cir. 2008) (“Excess liability policies, by contrast, do not provide first-dollar coverage for insured losses, but instead provide an additional layer of coverage for losses that exceed the limits of a primary liability policy. Coverage under an excess policy thus is triggered when the liability limits of the underlying primary insurance policy have been exhausted.”); St. Paul Mercury Ins. Co. v. Lexington Ins. Co., 78 F.3d 
The foregoing are just a few of the many questions regarding the ambiguities and the possible different meanings of the words used in non-cumulation clauses, such as the London version, and the alternative applications in long-tail liability cases to which the clauses were never intended to apply. Indeed, the ambiguity in non-cumulation clauses as applied to long-tail liability claims is highlighted by the fact that the insurers themselves proffer different meanings, applications, and interpretations of such clauses and cannot agree on what the language in the clauses means or how the clauses apply. ${ }^{88}$ For example, in In re Asbestos Insurance Coverage Cases, the San Francisco Superior Court held that the non-cumulation clause at issue was ambiguous "at best" and noted that, although the "insurers argue that the non-cumulation clauses are clear and unambiguous, they interpret the clauses differently."

\section{B. The "Reasonable Expectations" Doctrine}

Another staple of insurance policy interpretation law is that the policy should be interpreted to allow the coverage to fulfill the "reasonable expectations" of the policyholder. ${ }^{90}$ More than forty years

202, 209 (5th Cir. 1996) (“Texas law dictates that primary policies' limits must be exhausted before excess insurers become liable.”); Nat'l Union Fire Ins. Co. of Pittsburgh, Pa. v. Lawyers' Mut. Ins. Co., 885 F. Supp. 202, 205 (S.D. Cal. 1995) (“'Excess' or secondary coverage is coverage whereby, under the terms of the policy, liability attaches only after a predetermined amount of primary coverage has been exhausted." (internal quotation marks omitted) (quoting Olympic Ins. Co. v. Emp'rs Surplus Lines Ins. Co., 178 Cal. Rptr. 908, 910 (Cal. Ct. App. 1981))); Rhone-Poulenc, Inc. v. Int'l Ins. Co., 877 F. Supp. 1170, 1175 (N.D. Ill. 1995) (“Excess insurance 'kicks in’ to provide additional coverage once the policy limits of other available insurance are exhausted.").

88. See, e.g., In re Asbestos Insurance Coverage Cases, Judicial Council Coordination Proceeding No. 1072, at 30-32 (Cal. Super. Ct. Aug. 29, 1988), in 2-21 MEALEY's Litig. ReP.: INS. (Sept. 14, 1988). See also Viking Pump, Inc. v. Century Indem. Co., C.A. No. 1465-VCS, 2009 WL 3297559 , at $* 29$ n.165 (Del. Ch. Oct. 14, 2009) (recognizing the complexity of applying noncumulation clauses in the multiple-insurer context).

89. No. 1072 at 31-32.

90. See, e.g., 1 BROOK ET AL., supra note 74, § 2.02[1]; RoBERT E. KeETON \& AlAN I. Widiss, INSURANCE LAW: A GUIDE TO FUNDAMENTAL PRINCIPLES, LEGAL DOCTRINES, AND COMMERCIAL PRACTICES § 6.3(a)(3) (Student ed. 1988); 4 LONG, supra note 74, §16.07; 1 Ostrager \& NEWMAN, supra note 74, § 1.03[b][2][B] (identifying courts in forty-two states that have expressed support for, or applied a form of, the reasonable expectations doctrine); 2 RUSS \& SEGALLA, supra note 74, § 22-11; STEMPEL, supra note 74, §§ 11.1-2. Courts recognize the doctrine. See, e.g., AIU Ins. Co. v. Superior Court, 799 P.2d 1253, 1264 (Cal. 1990) (en banc) (noting that ambiguous coverage clauses of insurance policies are to be interpreted broadly to "protect[] the objectively reasonable expectations of the insured"); Roland v. Ga. Farm Bureau Mut. Ins. Co., 462 S.E.2d 623, 625 (Ga. 1995) ("A contract of insurance should be strictly construed against the insurer and read in favor of coverage in accordance with the reasonable expectations of the insured.”); A.B.C. Builders, Inc. v. Am. Mut. Ins. Co., 661 A.2d 1187, 1190 (N.H. 1995) (“[T]he policy language must be so clear as to create no ambiguity which might affect the insured's reasonable expectations.'” (quoting 
ago, then-Professor Robert Keeton wrote a seminal article regarding the "reasonable expectations" doctrine. ${ }^{91}$ In his subsequent treatise, thenJudge Keeton summarized the doctrine as follows:

In general, courts will protect the reasonable expectations of applicants, insureds, and intended beneficiaries regarding the coverage afforded by insurance contracts even though a careful examination of the policy provisions indicates that such expectations are contrary to the expressed intention of the insurer. ${ }^{92}$

Cacavas v. Me. Bonding \& Cas. Co., 512 A.2d 423, 425 (N.H. 1986))); Fed. Ins. Co. v. Century Fed. Sav. \& Loan Ass'n, 824 P.2d 302, 308 (N.M. 1992) (noting that the court will give effect to policyholder's reasonable expectations in construing policy language); Mills v. Agrichemical Aviation, Inc., 250 N.W.2d 663, 671-73 (N.D. 1977) (invoking doctrine of reasonable expectations to discern intentions of parties and impose liability on insurer).

91. See Robert E. Keeton, Insurance Law Rights at Variance With Policy Provisions, 83 HARV. L. REV. 961 (1970).

92. KEETON \& WIDISS, supra note 90, at 633. For commentary regarding the reasonable expectations doctrine, see Kenneth S. Abraham, Judge-Made Law and Judge-Made Insurance: Honoring the Reasonable Expectations of the Insured, 67 VA. L. REV. 1151 (1981); Roger C. Henderson, The Doctrine of Reasonable Expectations in Insurance Law After Two Decades, 51 OHIO ST. L.J. 823 (1990) (providing a detailed historical account of the doctrine and asserting that the doctrine is principled and can be applied within justiciable guidelines); Robert H. Jerry II, Insurance, Contract, and the Doctrine of Reasonable Expectations, 5 ConN. INS. L.J. 21 (1998) (discussing the doctrine as conceptualized by Keeton); William A. Mayhew, Reasonable Expectations: Seeking a Principled Application, 13 PEPP. L. REv. 267, 287-96 (1986) (formulating standards for applying the doctrine); Mark C. Rahdert, Reasonable Expectations Reconsidered, 18 ConN. L. REv. 323, 392 (1986) (arguing for refinements based on the doctrine's allegedly fading appeal and contending that courts should "discard their unfortunate tendency to speak the platitudes of reasonable expectations without undertaking a careful and systematic analysis”). While there is broad acceptance of the doctrine, judicial interpretation and application of the doctrine varies. See Jeffrey W. Stempel, Unmet Expectations: Undue Restriction of the Reasonable Expectations Approach and the Misleading Mythology of Judicial Role, 5 ConN. INs. L.J. 181, 182-83, 191 (1998) (describing judicial approaches and noting both liberal and narrow approaches among the numerous states that have adopted the doctrine); Peter Nash Swisher, A Realistic Consensus Approach to the Insurance Law Doctrine of Reasonable Expectations, 35 TORT \& INS. L.J. 729 (2000) (exploring judicial responses and proposing a middle ground approach); Laurie Kindel Fett, Note, The Reasonable Expectations Doctrine: An Alternative to Bending and Stretching Traditional Tools of Contract Interpretation, 18 WM. MitCheLL L. REV. 1113 (1992) (exploring the doctrine under Minnesota law); Scott B. Krider, Comment, The Reconstruction of Insurance Contracts Under the Doctrine of Reasonable Expectations, 18 J. MARSHALL L. REV. 155 (1984) (arguing that regulatory efforts address the underlying problems in the insurance industry in a manner superior to judicial use of reasonable expectations); William Mark Lashner, Note, A Common Law Alternative to the Doctrine of Reasonable Expectations in the Construction of Insurance Contracts, 57 N.Y.U. L. REV. 1175, 1208 (1982) (arguing that "any provision which undercuts the bargained-for insurance coverage must [be] specifically explained to the insured" to be enforceable); Stephen J. Ware, Comment, A Critique of the Reasonable Expectations Doctrine, 56 U. CHI. L. REv. 1461 (1989) (providing a "law and economics" critique of the doctrine). 
As Professor Mootz more recently commented, "[i]n other words, even when the policy language unambiguously precludes coverage, under certain circumstances, courts will hold that coverage exists." ${ }^{\text {"93 }}$

Stated differently, the policyholder should receive coverage that matches its objectively reasonable expectations even if the policy language does not expressly support such coverage. Thus, for example, a policyholder that is in the business of selling products can reasonably expect that it will receive coverage for product liability claims related to those products when it buys commercial general liability insurance for purposes of insuring itself against product liability claims. So, in oversimplified terms, if an insurer sells and accepts premiums for insurance that covers product liability claims, then courts generally should interpret the policy to cover product liability claims regardless of the insurer's interpretation of the policy or which exclusions the insurer argues should apply.

So, how does this doctrine apply to non-cumulation clauses? Well, in general, a policyholder can reasonably expect to receive payment of the full amount of the loss up to the policy limits despite the presence of a non-cumulation clause if the policyholder both paid a premium for the policy $^{94}$ and won determination that a covered loss triggered the policy.

93. Francis J. Mootz III, Insurance Coverage of Employment Discrimination Claims, 52 U. MIAMI L. REV. 1, 22 (1997).

94. Although automobile insurance is a much more heavily regulated area of insurance law that largely is governed by statutes and public policy rather than policy wording, numerous courts throughout the country have held that, despite policy language which purportedly limits a policyholder's recovery to a single policy limit, policyholders can recover multiple policy limits—or "stack" limits_-in automobile insurance policies where the policyholder paid a separate premium for each policy limit and, therefore, is entitled to receive the benefit of the bargain. See, e.g., N. River Ins. Co. v. Tabor, 934 F.2d 461, 466 (3d Cir. 1991) ("The other main reason cited by the Pennsylvania courts in striking down anti-stacking provisions is protection of the reasonable expectations of the insured. This reflects the concept that the insured, having paid multiple premiums, is entitled reasonably to believe that he has multiple coverage ....”); Sturdy v. Allied Mut. Ins. Co., 457 P.2d 34, 42 (Kan. 1969) ("When [one] pay[s] a double premium [one] expect[s] double coverage.”), superseded by statute, Act of Apr. 24, 1981, ch. 192, § 1(d), 1981 Kan. Sess. Laws 836 (1981) (codified at KAN. STAT. ANN. § 40-284(d)), as recognized in Farmers Ins. Co. v. Gilbert, 802 P.2d 556 (1990); Allstate Ins. Co. v. Dicke, 862 S.W.2d 327, 329 (Ky. 1993) (rejecting an anti-stacking provision because "when separate items of 'personal' insurance are bought and paid for, there is a reasonable expectation that the coverage will be provided"); Chaffin v. Ky. Farm Bureau Ins. Cos., 789 S.W.2d 754, 756 (Ky. 1990) (stating that public policy requires that a policyholder has a reasonable expectation that payment of separate premiums results in separate coverages); Jimenez v. Found. Reserve Ins. Co., 757 P.2d 792, 794 (N.M. 1988) (finding stacking appropriate based upon the reasonable expectations of the insured who purchased multiple coverages); Wilson v. Allstate Ins. Co., 912 P.2d 345, 347 (Okla. 1996) (holding that insured could stack underinsured benefits under two policies where insurance company collected higher premium for two cars which was almost double the premium charged for single-car coverage); Schult v. Rural 


\section{The Construction of the Policy as a Whole}

The third policy interpretation principle applicable to noncumulation clauses provides that, if possible, courts should interpret the policy in a way that attempts to reconcile the various provisions of the policy and attempts to give effect to all of the policy's provisions. ${ }^{95}$ In essence, this principle requires that courts, if possible, give effect to all of the policy's provisions in a way that is consistent with the purpose of the policy as a whole.

So how does this doctrine apply to a clause that is hopelessly ambiguous and is interpreted by some insurers in a way that is contrary to the reasonable expectations of the policyholder? As is further discussed below in Part V, non-cumulation clauses should be treated in the same way that "other insurance" clauses have been applied, because "other insurance" clauses purportedly serve a similar function as noncumulation clauses-i.e., they attempt to shift liability from one insurer to another insurer. Of course, "other insurance" clauses should not impact the recovery of the policyholder, but, instead, only should come into play when insurers fight among themselves to apportion the liability. ${ }^{96}$ Indeed, to the extent the clause would allow an insurer to

Mut. Ins. Co., 536 N.W.2d 135, 138 (Wis. Ct. App. 1995) (holding that where insured paid separate premiums he was entitled to stack coverage regardless of anti-stacking clauses).

95. See, e.g., GA. CODE ANN. § 13-2-2(4) (West 2003 \& Supp. 2010) (requiring that courts interpret a contract as a whole); Rothenberg v. Lincoln Farm Camp, Inc., 755 F.2d 1017, 1019 (2d Cir. 1985) (applying New York law and finding that "an interpretation that gives a reasonable and effective meaning to all the terms of a contract is generally preferred to one that leaves a part unreasonable or of no effect”); Fireman's Fund Ins. Co. v. Allstate Ins. Co., 286 Cal. Rptr. 146, 15556 (Cal. Ct. App. 1991) ("In short, an insurance contract 'is to be construed in a manner which gives meaning to all its provisions in a natural, reasonable, and practical manner, having reference to the risk and subject matter and to the purposes of the entire contract.'” (quoting Barrett v. Farmers Ins. Grp., 220 Cal. Rptr. 3d 135, 137 (Cal. Ct. App. 1985))); Weiss v. Bituminous Cas. Corp., 319 N.E.2d 491, 495 (Ill. 1974) (stating provisions in an insurance policy should be interpreted in context of entire policy).

96. See, e.g., Koppers Co. v. Aetna Cas. \& Sur. Co., 98 F.3d 1440, 1454 (3d Cir. 1996) (finding that under "all sums" allocation, an "other insurance" clause does not prohibit the policyholder from selecting the policy to respond, but rather permits an insurer to seek contribution from other insurers); Keene Corp. v. Ins. Co. of N. Am., 667 F.2d 1034, 1049-50 (D.C. Cir. 1981) (noting that "other insurance" provisions of each policy provide a scheme by which the insurer's liability is to be apportioned, rather than saddle a single insurer with full liability); Aerojet-Gen. Corp. v. Transp. Indem. Co., 948 P.2d 909, 942 (Cal. 1997) (Chin, J., concurring in part and dissenting in part) (disapproving of the majority's holding that other insurance clauses were without effect under "all sums” scheme); Owens-Corning Fiberglas Corp. v. Am. Centennial Ins. Co., 660 N.E.2d 770, 79495 (Ohio Ct. Com. Pl. 1995) (holding that it is within insured's discretion to select which triggered policy will be obligated to pay in full on a particular claim); J.H. France Refractories Co. v. Allstate Ins. Co., 626 A.2d 502, 508-09 (Pa. 1993) (finding "that each insurer [that] was on the risk ... is a primary insurer" and that the insured "should be free to select the policy or policies under which it is 
"escape" liability for a loss to the detriment of the policyholder, numerous courts have held such a result is impermissible. ${ }^{97}$

One version of an "other insurance" clause is known as an "excess" "other insurance" clause, which typically provides that coverage is not available under the policy until the loss at issue exceeds the amount of insurance provided by other policies. ${ }^{98}$ "Excess" "other insurance" clauses commonly are worded as follows: "If there is other insurance

to be indemnified”).

97. See, e.g., Greene, Tweed \& Co. v. Hartford Accident \& Indem. Co., Civil Action No. 033637, 2006 WL 1050110, at *13-16 (E.D. Pa. Apr. 21, 2006) (holding a non-cumulation clause invalid as an unenforceable escape clause because its operation under the circumstances of the case would have totally abrogated coverage for the policyholder); UTI Corp. v. Fireman's Fund Ins. Co., 896 F. Supp. 362, 378-79 (D.N.J. 1995) (invalidating non-cumulation clause as an unenforceable escape clause, stating that it is "unacceptable for an insurance company to provide no coverage under a policy for which it received premiums”" (internal quotation marks omitted) (quoting Contrans, Inc. v. Ryder Truck Rental, Inc., 836 F.2d 163, 166 (3d Cir. 1987))); Varian Assocs., Inc. v. Aetna Cas. \& Sur. Co., No. 944196, at 30-31 (Cal. Super. Ct. 1997), in 11-11 MEALEY’s LiTIG. REP.: INS. (Jan. 21, 1997) (refusing to enforce non-cumulation clause that purports "to reduce or eliminate the limits of liability of a policy because of the existence of other insurance covering the same loss" as a disfavored “escape clause”); In re Asbestos Insurance Coverage Cases, Judicial Council Coordination Proceeding No. 1072, at 30-32 (Cal. Super. Ct. Aug. 29, 1988), in 2-21 MEALEY's LITIG. REP.: INS. (Sept. 14, 1988) (declining to apply a non-cumulation provision because it was (1) ambiguous; (2) merely another form of "other insurance” clause; and (3) difficult if not impossible to apply in the context of thousands of asbestos-related bodily injury claims).

98. See Douglas R. Richmond, Issues and Problems in "Other Insurance," Multiple Insurance, and Self-Insurance, 22 PEPP. L. REV. 1373, 1385 (1995) (noting that an excess clause provides that an insurer will pay a loss only after other available insurance is exhausted). See also Ind. Ins. Co. v. Mission Nat'l Ins. Co., 874 F.2d 631, 634 (9th Cir. 1989) (applying Washington law); Hennes Erecting Co. v. Nat'l Union Fire Ins. Co. of Pittsburgh, Pa., 813 F.2d 1074, 1077 (10th Cir. 1987) (applying Kansas law); Horace Mann Ins. Co. v. United Int'l Ins. Co., 762 F. Supp. 1470, 1473-74 (M.D. Ala. 1990) (applying Alabama law), aff'd, 932 F.2d 1443 (11th Cir. 1991); Progressive Cas. Ins. Co. v. Travelers Ins. Co., 735 F. Supp. 15, 17-18 (D. Me. 1990) (applying Maine law); Liberty Mut. Ins. Co. v. Pac. Indem. Co., 579 F. Supp. 140, 143 (W.D. Pa. 1984) (applying Pennsylvania law); Ark. Poultry Fed'n Ins. Trust v. Lawrence, 805 S.W.2d 653, 660-61 (Ark. Ct. App. 1991); CSE Ins. Grp. v. Northbrook Prop. \& Cas. Co., 29 Cal. Rptr. 2d 120, 122-23 (Cal. Ct. App. 1994); Empire Cas. Co. v. St. Paul Fire \& Marine Ins. Co., 764 P.2d 1191, 1199 (Colo. 1988); Allstate Ins. Co. v. Exec. Car \& Truck Leasing, Inc., 494 So. 2d 487, 489 (Fla. 1986); Ga. Mut. Ins. Co. v. S. Gen. Ins. Co., 351 S.E.2d 658, 659-60 (Ga. Ct. App. 1986); Cont'l Nat'l Am. Ins. Co. v. Aetna Life \& Cas. Co., 542 N.E.2d 954, 956-58 (Ill. App. Ct. 1989); Cincinnati Ins. Co. v. Am. Alt. Ins. Corp., 866 N.E.2d 326, 329 (Ind. Ct. App. 2007); Motor Club of Iowa Ins. Co. v. Iowa Mut. Ins. Co., 508 N.W.2d 634, 637-38 (Iowa 1993); Dean v. State Farm Mut. Auto. Ins. Co., 518 So. 2d 1115, 1118 (La. Ct. App. 1987); Universal Underwriters Ins. Co. v. Allstate Ins. Co., 638 A.2d 1220, 1224 (Md. Ct. Spec. App. 1994); Nat'l Indem. Co. v. Budget Rent A Car Sys., Inc., 489 N.W.2d 175, 176 (Mich. Ct. App. 1992) (per curiam); Polenz v. Farm Bureau Ins. Co. of Neb., 419 N.W.2d 677, 684 (Neb. 1988); Universal Underwriters Ins. Co. v. Allstate Ins. Co., 592 A.2d 515, $516-17$ (N.H. 1991); Rogers v. Snappy Car Rental, Inc., 639 A.2d 1154, 1160 (N.J. Super. Ct. Law Div. 1993); Lumber Mut. Ins. Co. v. Lumberman’s Mut. Cas. Co., 588 N.Y.S.2d 630, 631 (N.Y. App. Div. 1992); Aetna Cas. \& Sur. Co. v. Cont'l Ins. Co., 429 S.E.2d 406, 409 (N.C. Ct. App. 1993); Erie Ins. Grp. v. Nationwide Mut. Ins. Co., 585 N.E.2d 464, 471-72 (Ohio Ct. App. 1989); Aetna Cas. \& Sur. Co. v. Nat’l Union Fire Ins. Co., 353 S.E.2d 894, 896-97 (Va. 1987). 
against a loss covered under this policy the insurance provided under this policy shall be excess insurance over any other valid and collectible insurance."99

Another type of "other insurance" clause is known as an "escape" clause, which sometimes is worded as follows: "Provided that where the Assured is, irrespective of this insurance, covered or protected against any loss or claim which would otherwise have been paid by the Assurer, under this policy, there shall be no contribution by the Assurer on the basis of double insurance or otherwise."

When two or more policies cover a policyholder's loss or liability and contain an "other insurance" clause similar to the examples abovewhich, along with non-cumulation clauses, purport to avoid or shift coverage obligations to other insurers - then courts generally consider the clauses to be mutually repugnant ${ }^{101}$ and, thus, unenforceable. ${ }^{102}$ In

99. Kahn, supra note 87, at 595 (citing Cosmopolitan Mut. Ins. Co. v. Cont'l Cas. Co., 147 A.2d 529 (N.J. 1959)). Another variation provides "[t]he insurance under this policy shall be excess insurance over any other valid and collectible insurance available to the insured, either as an insured under another policy or otherwise.” Cosmopolitan Mut. Ins. Co., 147 A.2d at 531 (internal quotation marks omitted).

100. Elf Exploration, Inc. v. Cameron Offshore Boats, Inc., 863 F. Supp. 386, 392 (E.D. Tex. 1994).

101. Insurance policy provisions are "mutually repugnant" if the enforcement of one of them precludes the enforcement of the other. See, e.g., Underwriters at Lloyd's, London v. Pike, 977 F.2d 1278, 1279-80 (8th Cir. 1992) (concluding that both insurers' escape clauses "are mutually repugnant and both policies will share pro rata liability”); State Farm Mut. Auto. Ins. Co. v. Gen. Mut. Ins. Co., 210 So. 2d 688, 694-96 (Ala. 1968) (finding that policies containing mutually repugnant "excess insurance" clauses should share the loss through apportionment); Empire Cas. Co. v. St. Paul Fire \& Marine Ins. Co., 764 P.2d 1191, 1199 (Colo. 1988) (en banc) (voiding competing insurers' "other insurance” clauses); Buckson v. Pa. Nat'l Mut. Cas. Ins. Co., No. 97C-04-009, 1999 Del. Super. LEXIS 301, at *13-14 (Del. Super. Ct. Mar. 15, 1999) (finding competing policies' "other insurance" provisions to be "mutually repugnant" and therefore void); Rogers, 639 A.2d at 1160 (finding other insurance clauses to be mutually repugnant); Lamb-Weston, Inc. v. Or. Auto. Ins. Co., 341 P.2d 110, 118-19 (Or. 1959) (holding that when any "escape” or "excess" clauses come in conflict with another "other insurance" clause, they are mutually repugnant).

102. See, e.g., Car \& Truck Leasing, 494 So. $2 \mathrm{~d}$ at 489 (finding that conflicting excess insurance policies "cancel each other out" and result in pro rata apportionment); Ill. Nat'l Ins. Co. v. Farm Bureau Mut. Ins. Co., 578 N.W.2d 670, 672 (Iowa 1998) (“[W]hen confronted with mutually repugnant excess or escape clauses, the loss must be prorated between the insurers in accordance with the policy limits.”); Great N. Ins. Co. v. Mount Vernon Fire Ins. Co., 708 N.E.2d 167, 170 (N.Y. 1999) ("[I]f ... two policies are excess to one another, the two 'other insurance' clauses cancel each other out and the companies must apportion the costs . . . on a pro rata basis.”); Iodice v. Jones, 514 S.E.2d 291, 293 (N.C. Ct. App. 1999) ("Where it is impossible to determine which policy provides primary coverage due to identical 'excess' clauses, 'the clauses are deemed mutually repugnant and neither ... will be given effect.”' (quoting N.C. Farm Bureau Mut. Ins. Co. v. Hilliard, 369 S.E.2d 386, 388 (1998))); Buckeye Union Ins. Co. v. State Auto. Mut. Ins. Co., 361 N.E.2d 1052, 1053-54 (Ohio 1977) ("Since there can be no primary insurance of the risk where there are conflicting excess clauses, the excess clauses a fortiori cannot be a valid means of 
such circumstances, after the policyholder has been paid in full, the courts then prorate the loss or liability between the triggered policy years. ${ }^{103}$

According to some commentators, "other insurance" clauses are also really intended only to "prevent double recoveries by insureds." 104 Consequently, "[g]iven the purpose of the 'other insurance' clauses, these provisions do not provide any contractual basis for allocating a portion of the insured's loss to [the insured]."105 Thus, "other insurance" clauses are really intended to allow "equitable contribution" between and among insurers after one or more of the insurers has paid the policyholder's claim in full. ${ }^{106}$

The reasoning of these commentators and the decisions discussed and cited in this Part regarding "other insurance" clauses apply equally to non-cumulation clauses. Non-cumulation clauses similarly purport to shift the liability for a loss from the policy at issue to other policies issued in prior years, so the same principles apply. Consequently, such clauses should be understood to be intended only to prevent "double recoveries" by policyholders, and thus, the clauses only allow for "equitable contribution" between and among insurers after the policyholder's claim has been paid in full by one or more of the insurers.

\section{HOW COURTS SHOULD INTERPRET AND APPLY NON-CUMULATION Clauses to LONG-TAIL Claims}

With this factual and legal background in mind, one can ascertain a framework for the courts' interpretation and application of noncumulation clauses in the context of long-tail claims. The framework has two primary components.

establishing only 'secondary' liability.”); see also 8A JoHn ALAN APPLEMAN \& JEAN APPLEMAN, INSURANCE LAW AND PRACTICE $§ 4909$ (1981); James R. Adams, Other Insurance in 4 THE LAW OF LiABILITY INSURANCE § 22.04[1] n.3 (Sally A. Swiss ed., 1999). Many courts recognize pro rata allocation of the loss. Ind. Ins. Co., 874 F.2d at 634 ("[I]f there are two policies of excess insurance and a literal construction of each policy would mean that neither would have to pay, the policies are mutually repugnant and a court will construe the contracts to require each insurer to pay its appropriate share.”).

103. See supra notes $101-02$ and accompanying text.

104. John H. Mathias, Jr., John D. Shugrue, \& Brian C. Bendig, Allocation: J.H. France and the Insureds' Right to Select from Multiple Triggered Policies, COVERAGE, Mar./Apr. 1994, at 19, 22.

105. Id.

106. Id. at 21 . 


\section{A. Courts Should Construe Non-Cumulation Clauses in Favor of Policyholders}

The first part of the framework provides that, because many versions of the clause are hopelessly ambiguous when applied to long-tail claims for all of the reasons discussed above, courts should interpret them in favor of the policyholder. Indeed, because the courts that have interpreted and applied a non-cumulation clause have reached different conclusions as to its meaning and application, such clauses generally must be ambiguous. ${ }^{107}$ Further, such a result is consistent with the reasonable expectations of the policyholder, who can and should expect its insurers to pay for covered losses instead of attempting to shift their coverage obligations to other insurers. Consequently, under wellestablished insurance law regarding policy interpretation, courts should construe non-cumulation clauses in favor of coverage for the policyholder.

Such a result should come as no surprise to insurers. Even one of the London underwriters responsible for the London version of the clause that is still found in many policies today has acknowledged that long-tail claims had not yet been recognized when the clause was drafted and allocation rules, such as "all sums" allocation, did not exist. ${ }^{108}$ Thus, the clause could not have been intended to apply to long-tail claims-such as asbestos bodily injury and environmental property damage-under current allocation rules. To the contrary, the drafters originally intended

107. See, e.g., Sec. Ins. Co. of Hartford v. Investors Diversified Ltd., 407 So. 2d 314, 316 (Fla. Dist. Ct. App. 1981) ("The insurance company contends that the language is not ambiguous, but we cannot agree and offer as proof of that pudding the fact that the Supreme Court of California and the Fifth Circuit in New Orleans have arrived at opposite conclusions from a study of essentially the same language.”); Crawford v. Prudential Ins. Co. of Am., 783 P.2d 900, 908 (Kan. 1989) (“[T]he reported cases are in conflict, the trial judge and the Court of Appeals reached different conclusions and the justices of this court [disagree]. Under such circumstances, the clause is, by definition, ambiguous and must be interpreted in favor of the insured.”); Allstate Ins. Co. v. Hartford Accident \& Indem. Co., 311 S.W.2d 41, 47 (Mo. Ct. App. 1958) ("Since we assume that all courts adopt a reasonable construction, the conflict is of itself indicative that the word as so used is susceptible of at least two reasonable interpretations, one of which extends the coverage to the situation at hand.”); George H. Olmsted \& Co. v. Metro. Life Ins. Co., 161 N.E. 276, 277-78 (Ohio 1928) ("[T]he fact that [the] authority is in irreconcilable conflict, . . . coupled with the fact that the lower courts in the instant case are in disagreement..., presents [a] persuasive argument of the ambiguity of the clause .... .”; Cohen v. Erie Indem., Co., 432 A.2d 596, 599 (Pa. Super. Ct. 1981) (“The mere fact that [courts differ on the construction of the provision] itself creates the inescapable conclusion that the provision in issue is susceptible to more than one interpretation.”). See also 1 BROOK ET AL., supra note 74, § 2.02[1]; STEMPEL, supra note 74, § 5.8; 4 LONG, supra note 74, § 16.06; Marvel, supra note 76, at 1253 .

108. Wilson Deposition I, supra note 21, at 98-100. 
only to prevent a policyholder from receiving a double recovery by accessing coverage under differently worded policy forms as the insurance industry transitioned from one policy form to another in the early 1960s. ${ }^{109}$

This conclusion also comports with the various states' allocation laws. In jurisdictions that have adopted "all sums" allocation, if noncumulation clauses were applied as requested by certain insurers, then the policyholder would be stripped of its right to select the policy year that will provide coverage because the insurers could effectively veto the policyholder's selection. Similarly, in pro rata allocation jurisdictions, the insurers already have been given a discount on their obligations to the policyholder because they are only being held responsible for a portion of the policyholder's liabilities.

Moreover, applying non-cumulation clauses as requested by the insurers would be inconsistent with public policy, which encourages settlements. ${ }^{110}$ If a policyholder were required to "credit" either the amounts it has received in settlements or the entire policy limits of the settled policies toward the policy limits of non-settling insurers' policies in later policy years, then the policyholder would have little or no incentive to settle. Conversely, if holdout insurers could reduce their policies' limits by amounts paid by settling insurers in earlier policy years or the entire policy limits of prior-incepting policies that are settled, then insurers would have an incentive to hold out instead of settling.

In short, so long as the policyholder does not receive a double recovery, then the policyholder should receive the benefit of its bargain with its insurers, which did, after all, receive a premium for the policy.

109. Id. at 76-78, 89-90, 158. See also Fields, supra note 24, at 32-34.

110. See, e.g., Deleonardis v. U.S. Dep’t. of Health \& Human Servs., No. 93-2856, 1994 WL 499623, at *1 (5th Cir. Aug. 22, 1994) (noting that settlement is favored and encouraged by the court); Murchison v. Grand Cypress Hotel Corp., 13 F.3d 1483, 1486 (11th Cir. 1994) ("We favor and encourage settlements in order to conserve judicial resources.”); Justine Realty Co. v. Am. Nat'l Can Co., 976 F.2d 385, 391 (8th Cir. 1992) (noting preference for settlement); United States v. Cannons Eng'g Corp., 899 F.2d 79, 84 (1st Cir. 1990) (noting public policy to encourage settlement); Bass v. Phoenix Seadrill/78, Ltd., 749 F.2d 1154, 1164 (5th Cir. 1985) (“[P]ublic policy favors voluntary settlements which obviate the need for expensive and time-consuming litigation.”); Donovan v. Robbins, 752 F.2d 1170, 1177 (7th Cir. 1985) (noting principle that settlements are favored); Miles v. Nw. Mut. Life Ins. Co., 677 F. Supp. 2d 1312, 1315 (M.D. Fla. 2009) (stating that settlement is favored to conserve judicial resources); Morales-Arcadio v. Shannon Produce Farm, Inc., No. 605CV062, 2008 WL 4421398, at *1 (S.D. Ga., Sept. 29, 2008) (noting court’s "duty to uphold social policy favoring settlement”); City of New York v. Exxon Corp., 697 F. Supp. 677, 692 (S.D.N.Y. 1988) (noting preference for settlement in CERCLA litigation). 


\section{B. Courts Should Treat Non-Cumulation Clauses Like "Other Insurance” Clauses}

The second part of the framework provides that, because they purport to shift liability for a loss from one policy to other policies, noncumulation clauses are just another variation of "other insurance" clauses that commonly are found in commercial general liability policies. Consequently, they should be given the same effect as "other insurance" clauses. As an initial matter, as discussed above in Part IV.C., "other insurance" clauses should not impact the policyholder's recovery. ${ }^{111}$ As a result, such clauses only impact the allocation of the loss among insurers after the policyholder has been paid in full.

Further, in contribution actions between insurers, the doctrines of contra proferentem and "reasonable expectations" do not necessarily apply because the dispute is between insurers, not an insurer and a policyholder. ${ }^{112}$ Thus, many of the arguments set forth in this Article

111. See, e.g., Koppers Co. v. Aetna Cas. \& Sur. Co., 98 F.3d 1440, 1454 (3d Cir. 1996) (finding that under "all sums" allocation, an "other insurance" clause does not prohibit the policyholder from selecting the policy to respond, but rather permits an insurer to seek contribution from other insurers); Keene Corp. v. Ins. Co. of N. Am., 667 F.2d 1034, 1050 (D.C. Cir. 1981) (finding that the insured can collect from any triggered insurer and liability is apportioned among all); Greene, Tweed \& Co. v. Hartford Accident \& Indem. Co., Civil Action No. 03-3637, 2006 WL 1050110, at *13-16 (E.D. Pa. Apr. 21, 2006) (finding “non-cumulation” clause unenforceable); UTI Corp. v. Fireman's Fund Ins. Co., 896 F. Supp. 362, 378-79 (D.N.J. 1995) (finding "other insurance” clause unenforceable); Aerojet-Gen. Corp. v. Transp. Indem. Co., 948 P.2d 909, 942 (Cal. 1997) (Chin, J., dissenting) (characterizing majority holding as finding other insurance clauses were without effect under "all sums" scheme); Varian Assoc., Inc. v. Aetna Cas. \& Sur. Co., No. 944196, at 30-31 (Cal. Super. Ct. Jan. 9, 1997) in 11-11 MeALEY’s Litig. ReP.: INS. (Jan. 21, 1997) (finding "other insurance" clause to be a partial escape clause and giving it no effect); In re Asbestos Insurance Coverage Cases, Judicial Council Coordination Proceeding No. 1072, at 30-32 (Cal. Super. Ct. Aug. 29, 1988), in 2-21 MEALEY’s LiTIG. REP.: INS. (Sept. 14, 1988) (giving “non-cumulation” clauses no effect); Owens-Corning Fiberglas Corp. v. Am. Centennial Ins. Co., 660 N.E.2d 770, 794-95 (Ohio Ct. Com. Pl. 1995) (finding "other insurance" clause does not require pro rata allocation of liability); J.H. France Refractories Co. v. Allstate Ins. Co., 626 A.2d 502, 508-09 (Рa. 1993) (finding insured can select insurers from which to seek indemnification).

112. See, e.g., Parks Real Estate Purchasing Grp. v. St. Paul Fire \& Marine Ins. Co., 472 F.3d 33, 43 (2d Cir. 2006) (implying that contra proferentem only applies to ambiguity questions about policy between insurer and policyholder); James v. Zurich-Am. Ins. Co. of Ill., 203 F.3d 250, 258 (3d Cir. 2000) (noting that contra proferentem construction applies when contract dispute is between the insurer and its insured); U.S. Fid. \& Guar. Co. v. W. Cas. \& Sur. Co., 408 P.2d 596, 598 (Kan. 1965) (finding that in a dispute between two insurance companies, the court does not apply the rule of liberal interpretation that is necessary to protect a policyholder); Boston Ins. Co. v. Fawcett, 258 N.E.2d 771, 776 (Mass. 1970) (noting that contra proferentem does not apply where "all the parties to the litigation are large insurance companies long engaged in far-flung activities in that field of economic activity”). But see Commercial Standard Ins. Co. v. Gen. Trucking Co., 423 So. 2d 168, 171 (Ala. 1982) (justifying a construction against an insurer even where both parties are equally informed insurers). 
regarding the interpretation of non-cumulation clauses with respect to the policyholder do not apply in actions between insurers.

With that said, in contribution actions between insurers, a court should allocate the loss in accordance with the jurisdiction's law relating to allocation and "other insurance" clauses. If, for example, all of the policies at issue contain non-cumulation clauses, then courts in "all sums" and pro rata jurisdictions should allocate the loss on a pro rata basis between the insurers because the non-cumulation clauses are mutually repugnant. ${ }^{113}$ If the policies do not all contain non-cumulation clauses, then courts in an "all sums" jurisdiction should apply the clause in favor of the later-issued policies to the extent that there are no competing policy provisions that would change the result. In pro rata jurisdictions, the insurers already have received a discount from their full policy obligations, so the clause would not apply. ${ }^{114}$ In jurisdictions such as New Jersey, which apply pro rata time on the risk allocation, ${ }^{115}$ the court should allocate the loss among the various triggered policies based upon the percentage of total insurance provided by each insurer.

\section{CONCLUSION}

The manner in which courts allocate long-tail claim liabilities raises critical questions in complex, multi-party litigation and has a significant impact on the financial obligations of the parties involved. Certain insurers' attempts to use non-cumulation clauses to reduce or eliminate their financial obligations for long-tail claims — such as asbestos bodily injury claims and environmental property damage claims-should be rejected with respect to the amount ultimately paid to the policyholder. Many versions of the clause are hopelessly ambiguous when applied to such claims under current insurance concepts such as continuous trigger and "all sums" allocation, which did not exist when the clauses were drafted. Nor was the existence of long-tail claims even recognized as such at the time the clauses were drafted. Consequently, non-cumulation clauses, such as the London version, were only intended to prevent the

113. See, e.g., supra note 101.

114. See, e.g., Spaulding Composites Co. v. Aetna Cas. \& Sur. Co., 819 A.2d 410, 422 (N.J. 2003) ("Once the court turns to pro rata allocation, it makes sense that the non-cumulation clause, which would allow the insurer to avoid its fair share of responsibility, drops out of the policy.").

115. See Carter-Wallace, Inc. v. Admiral Ins. Co., 712 A.2d 1116, 1124 (N.J. 1998) (allocating coverage among multiple liability insurers in proportion to the degree of the risks transferred or retained during the years of exposure). 
policyholder from obtaining a double recovery where two different types of policies covered the same loss. If such clauses have any relevance today, it is only for purposes of allocating losses among insurers after the policyholder has been made whole. Indeed, because non-cumulation clauses essentially are a variation on "other insurance" clauses, they should be treated like "other insurance" clauses and should not be applied to reduce the coverage that a policy otherwise affords. 